\title{
1a, 25-dihydroxy Vitamin D3 containing fractions of Catharanthus roseus leaf aqueous extract inhibit preadipocyte differentiation and induce lipolysis in 3T3- L1 cells
}

Anuj Kumar Borah ${ }^{1}$, Archana Singh ${ }^{1}$, Rafika Yasmin' ${ }^{1}$, Robin Doley ${ }^{1}$, Venkata Satish Kumar Mattaparthi ${ }^{1}$ and Sougata Saha ${ }^{2^{*}}$

\begin{abstract}
Background: To investigate the potential of Catharanthus roseus leaf aqueous crude extract (CRACE) as a regulator of adipocyte development and function.

Methods: 3T3-L1 adipogenesis model was used to investigate the effect of CRACE on adipogenesis. 3T3-L1 preadipocytes (for adipogenic differentiation) and mature 3T3-L1 adipocytes (for adipocyte function) were treated with non-toxic doses of CRACE. The outcomes were corroborated by intracellular lipid accumulation, expression of pro-and anti-adipogenic effector molecules. To investigate CRACE mediated lipolysis, CAMP accumulation, glycerol release and phosphorylation of key effector molecules were tested in treated mature adipocytes. Finally, the extract was fractionated to identify the active molecule/s in the extract.

Results: CRACE significantly reduced adipocyte differentiation by modulating PPARy expression. At early stage CRACE directly targeted Lipin1 expression and consequently impacted KLF7, subsequently expression of GATA2, CEBPa, SREBP1c were targeted, with PPARY expression, particularly curtailed. While CRACE significantly reduced several lipogenic genes like FAS and GPD1 in mature adipocytes, concomitantly, it greatly increased lipolysis resulting in decreased lipid accumulation in mature adipocytes. The increase in lipolysis was due to decreased Akt activation, increased CAMP level, and PKA activity. The fractionation of CRACE allowed identification of two fractions with potent anti-adipogenic activity. Both the fractions contained 1a, 25-dihydroxy Vitamin D3 as major component.
\end{abstract}

Conclusions: 1a, 25-dihydroxy Vitamin D3 containing CRACE can be developed into an effective anti-obesity formulation that decreases adipogenesis and increases lipid catabolism.

Keywords: Catharanthus roseus, Obesity, Lipolysis, Adipogenesis, 3T3-L1, Vitamin D3

\footnotetext{
* Correspondence: sougatasaha2009@gmail.com;

sougata.saha@bt.nitdgp.ac.in

${ }^{2}$ Department of Biotechnology, National Institute of Technology, Durgapur,

West Bengal 713209, India

Full list of author information is available at the end of the article
}

(c) The Author(s). 2019 Open Access This article is distributed under the terms of the Creative Commons Attribution 4.0 International License (http://creativecommons.org/licenses/by/4.0/), which permits unrestricted use, distribution, and reproduction in any medium, provided you give appropriate credit to the original author(s) and the source, provide a link to the Creative Commons license, and indicate if changes were made. The Creative Commons Public Domain Dedication waiver (http://creativecommons.org/publicdomain/zero/1.0/) applies to the data made available in this article, unless otherwise stated. 


\section{Background}

Adipose tissue development, function and its microenvironment have become potential caches to counter health issues like obesity, cardiovascular disease, type 2 diabetes, cancer and many more metabolic as well as physiological disturbances [1, 2]. During adipose tissue development new fat cells arise from preadipocytes by a highly regulated process, where committed cells undergo a clonal expansion phase, followed by differentiation. PPARY (Peroxisome Proliferator Activated Receptor $\gamma$ ) plays the role of a key regulator during the two-step adipogenic program, along with several other transcription factors playing positive and negative regulatory roles $[3,4]$. Dysregulations of adipogenesis leads to adverse repercussions like excessive accumulation of triacylglycerol (TAG) in adipocytes (hypertrophy) and increase in the number of adipocytes (hyperplasia). Both conditions contribute to obesity; which eventually changes the tissue microenvironment, leading to recruitment of pro-inflammatory macrophages, heightened inflammation and insulin resistance [5-7]. Thus restoring homeostasis in the adipocytes is argued to be a potential therapeutic, approach that is fairly commonly adopted. Three important factors associated with adipocyte homeostasis are differentiation, lipogenesis and lipolysis. Research with adipocytes as well as obese animal models have shown that, increased lipid metabolism and decreased adipogenesis can improve glucose utilization and beneficiary adipokine expression [8]. However, at present, the compounds approved for treating obesity mostly target appetite reduction and lipid digestion, with poor efficacy and many side effects. Thus it is necessary to search for new therapeutic agents to treat obesity, which has acquired the status of a global epidemic.

Herbal extracts are proven sources of therapeutic agents with many important drugs having been derived from plant metabolites. In search of new antiobesity therapeutic agents, the current study delved into plant extracts with potential effect on adipocytes. Catharanthus roseus (formerly known as Vinca rosea) which is locally known as nayantora/nayantara in eastern India, has many reports of its efficacy in traditional medicine against cancer, diabetes, liver disease etc. In addition, a recent study showed improved serum lipid profile after oral administration of $C$. roseus leaf juice to guinea pigs [9]. Nayantora is a bushy perennial herb of the Apocynaceae family, available in quite a few varieties. Its common names whether nayantara, nayantora or bright eyes, refers to characteristic darker centres or "eyes", at the centre of its flowers that range from white to lavender pink.
Hot water extract of the dried leaves has been taken for treatment of diabetes in India [10, 11], Jamaica [12], Brazil [13] and South Africa [14] among many other countries. Organic extracts of C. roseus are reported to have stimulatory effects on glucose utilization in 3T3-L1 cells [15]. However, no report on the effect of $C$. roseus extracts on adipose tissue development and adipocyte physiology exists. Neither the target tissues nor target molecules of this extract have been explored in depth in relation to adipocytes. In the current study, potential anti-obesity effect of $C$. roseus leaf extract was tested in an adipocyte cell culture model.

\section{Methods}

\section{Collection and identification of the plant sample}

Freely available Catharanthus roseus plant was collected from North Lakhimpur district of Assam, in India (Geographical coordinates: $27^{\circ} 14^{\prime} 10.7412 " \mathrm{~N}$ and $\left.94^{\circ} 5^{\prime} 45.0240^{\prime \prime} \mathrm{E}\right)$. The plant material was further identified by Dr. S. K. Singh (Scientist-D, Botanical Survey of India, Shillong) as Catharanthus roseus (L.) G. Don. The voucher specimen of this material has been deposited in a publicly available herbarium repository of Botanical Survey of India, Shillong (deposition No. BSI/ERC/Tech/Plant identification/2018/276).

\section{Preparation of the CRACE}

Leaves of the flowering plants were washed with water, shade dried and ground to powder. The powdered plant material $(5 \mathrm{~g})$ was mixed with $100 \mathrm{~mL}$ of distilled water and stirred at room temperature for $5 \mathrm{~h}$. The resulting slurry was incubated for $12 \mathrm{~h}$ at $4{ }^{\circ} \mathrm{C}$. The slurry was then centrifuged and the supernatant was syringe filtered to obtain the extract named "CRACE". The liquid CRACE was further lyophilized to get the powdered CRACE. The yield of lyophilisation was $8-8.3 \mathrm{mg}$ of powder per $\mathrm{mL}$ of liquid CRACE. The lyophilized powder was dissolved again in sterile water to obtain $10 \mathrm{mg} / \mathrm{mL}$ of CRACE stocks.

\section{Cell culture, differentiation and treatments}

3T3-L1 cells, L6 cells, HepG2 and Raw 264.7 cells were seeded at a density of $2 \times 10^{4}$ cells/well of a 96 well plate in culture medium containing DMEM (Himedia AL007A) with 10\% FBS and 1X antibiotic and antimycotic (maintenance medium) in a humidified $5 \% \mathrm{CO}_{2}$ incubator at $37^{\circ} \mathrm{C}$. When confluency of the cells reached approximately $70 \%$, the cells were exposed to different doses of the extract CRACE for $24 \mathrm{~h}$ or $48 \mathrm{~h}$; subsequently, and cell survivability was measured by MTT (Sigma M2128) assay following 
standard procedure [16, 17]. 3T3-L1 cells were differentiated following previously reported method with minor modifications [18, 19]. Briefly, 3T3-L1 cells were seeded $\left(3 \times 10^{5}\right.$ cells/well of a $35 \mathrm{~mm}$ dish) in maintenance medium and allowed to grow till $100 \%$ confluency. Differentiation was induced in confluent cells by replacing maintenance media with fresh maintenance media containing $1 \mu \mathrm{M}$ dexamethasone (Sigma D4902), $0.5 \mathrm{mM}$ Isobutylmethylxanthine (IBMX) (Sigma I7018) and $5 \mu \mathrm{g} / \mathrm{mL}(872$ nM) Insulin (Sigma I5500) (differentiation media). The day of induction is marked as 'day 0 '. On day 2 , the media was replaced with fresh maintenance media containing only $5 \mu \mathrm{g} / \mathrm{mL}(872.07 \mathrm{nM})$ of insulin and cells were incubated for 2 days. On day 4 the media was replaced with maintenance media and cells were grown for another 4 days to allow them to differentiate. By day 8, the 3T3-L1 preadipocytes had become adipocytes with accumulated lipid droplets. To test the effect of CRACE and $1 \alpha, 25$-dihydroxy Vitamin D3 (Sigma D1530) on differentiation, cells were exposed to the extract or the compound from day 0 to day 4 . To test the effect of CRACE and $1 \alpha$, 25-dihydroxy Vitamin D3 on mature adipocytes, the extract or the compound was added to the differentiated adipocytes on day 8 , and cells were grown for another 4 days, with change of medium every 2 days, unless mentioned otherwise. For expression analysis (mRNA and protein), and cell based assays (viz cAMP accumulation, glycerol release assay and lipid droplet size study), the liquid CRACE was used and represented as the $\mu \mathrm{g} / \mathrm{mL}$ equivalence of the powdered CRACE. The treatments for lipid accumulation study, during differentiation and post differentiation, were done with different concentrations of lyophilized powered CRACE, from the $10 \mathrm{mg} / \mathrm{mL}$ CRACE stocks.

\section{Oil red $O$ staining and quantification of lipid content and lipid droplet size}

Accumulated intracellular lipid was stained with Oil Red O (ORO) as described before with few modifications [19]. Briefly, cells were stained with $3: 2$ of $0.3 \%$ ORO in isopropanol and water for 5-10 min followed by three $60 \%$ isopropanol washes, and three water washes. Lipid content was measured by extracting ORO by isopropanol and measuring absorbance at $510 \mathrm{~nm}$. Lipid content was also measured by analyzing ORO fluorescence per frame of micrographs of stained cells by ImageJ software from $\mathrm{NIH}$ following earlier report [20]. To measure lipid droplet size, phase contrast and fluorescent micrographs of ORO stained cells were captured at 100X. Area of all lipid droplets from 5 individual images of ORO stained cells were measured using area measurement module of NLS element analysis D software.

\section{RNA isolation and semi quantitative RT PCR}

Total RNA was isolated from cultured cells using TRIzol (Invitrogen) and cDNA synthesis was done using cDNA synthesis kit (Clontech, Otsu, Japan; 6110A). Specific primer sequences (Additional file 1: Table S2) were used to amplify target genes. Intensities of bands were quantified by GelQuant.NET software (Biochemlabsolutions, Wayne, PA, USA).

\section{Western blotting}

Anti-PPAR $y$ was purchased from Thermo Scientific (MA5-14889); whereas anti- $\beta$-Tubulin Ab (AB0119) and anti- $\gamma$-Actin antibody (BB-AB0025) were purchased from BioBharati, India. Anti-PLN1, Anti-PKA substrate specific antibody (Anti pPLN1 antibody), Anti-AKT and Anti- pAKT(S473) were obtained from CST (CST 9349, 9621, $9272 \mathrm{~S}$ and $4060 \mathrm{~T}$ respectively). Blots were developed using West Femto (Invitrogen 34,094) or Clarity ECL substrate (Bio-Rad 1,705,060) and documented using chemidoc.

\section{Glycerol release assay}

3T3-L1 $\left(7.5 \times 10^{4}\right.$ cells/well) were seeded in 96 well plates and allowed to differentiate into mature adipocytes. On day 8 post differentiation, cells were transferred to Krebs Ringer Buffer (KRB buffer) with $4 \%$ fatty acid free BSA and $5 \mathrm{mM}$ D-glucose (lipolysis buffer). Lipolysis was induced by either $10 \mu \mathrm{M}$ isoproterenol (Sigma I6504) or CRACE $(500 \mu \mathrm{g} / \mathrm{mL}$ equivalent) in lipolysis buffer and incubated for $3 \mathrm{~h}$ in $\mathrm{CO}_{2}$ incubator. Similar treatments were also done after treating cells for $1 \mathrm{~h}$ with $10 \mu \mathrm{M}$ adenosine (Sigma A4036-5G) in lipolysis buffer. Subsequently, 3 $\mathrm{h}$ of isoproterenol or CRACE treatment in presence of $1 \mathrm{U} / \mathrm{mL}$ adenosine deaminase (Sigma 52,544-1ML) was initiated to remove adenosine mediated background inhibition [21]. To test the effect of PKA inhibition on CRACE induced lipolysis, mature adipocytes were serum starved for $3 \mathrm{~h}$. The cells were then pre-treated with $20 \mu \mathrm{M}$ PKA inhibitor H89 (Tocris 2910) for $1 \mathrm{~h}$ in lipolysis buffer, followed by 3 h treatment with $500 \mu \mathrm{g} / \mathrm{mL}$ equivalent CRACE or $10 \mu \mathrm{M}$ isoproterenol individually or together in presence of $20 \mu \mathrm{M} \mathrm{H} 89$. Uninduced and no treatment groups were taken as control. At the end of the treatments released glycerol was estimated using glycerol assay kit (Sigma MAK117).

cAMP accumulation assay

3T3-L1 (2X10 ${ }^{4}$ cells/well) were plated in white clear bottom 96 well plates (BD 353377) and grown 
overnight. Cells were serum starved for $3 \mathrm{~h}$. Cells were transferred to $100 \mu \mathrm{L}$ KRB buffer with $4 \%$ fatty acid free BSA and pre-treated with $0.5 \mathrm{mM}$ IBMX for $10 \mathrm{~min}$ followed by $15 \mathrm{~min}$ and $100 \mathrm{~min}$ of IBMX \pm CRACE $(500 \mu \mathrm{g} / \mathrm{mL}$ equivalent) treatment. Intracellular cAMP was measured using cAMP-Glo Kit (Promega V1501).

\section{Phytochemical analysis}

Identification of phytochemicals in the extract was performed following earlier reported methods. Briefly test for phenolics (ferric chloride test, phosphomolybdic acid test), flavonoids ( $\mathrm{NaOH}$ test, $\mathrm{Zn}-\mathrm{HCl}$ test, Shinoda test), saponins (foam test), tannins (Braemer's test), steroids (Salkowski test), reducing (Fehling test) and nonreducing sugars (Iodine test) were performed [22].

\section{HPLC fractionation of CRACE}

Reverse-Phase UHPLC was performed in Thermo Scientific Ultimate 3000 , to fractionate the extract CRACE, in a Phenomenex (Aeris Widepore) C18 column $(3.6 \mu, 200 \AA$, $250 * 2.10$ ). The loading volume was $200 \mu \mathrm{L}$ of $10 \mathrm{mg} / \mathrm{mL}$ CRACE. Flow rate maintained at $0.3 \mathrm{~mL} / \mathrm{min}$. Solvent A was Milli $\mathrm{Q}$ water $+0.1 \%$ Trifluoroacetic acid (TFA) and Buffer B was $80 \%$ Acetonitrile $(\mathrm{ACN})+0.1 \% \mathrm{TFA}+$ Milli $Q$ water. The separation was done with the set up as: 0-9 min, 0\% Buffer B; 9-12 min, 5\% Buffer B; 12-42 min, 30\% Buffer B; $42-48$ min, 100\% Buffer B; 48-54 min, 100\% Buffer B; and finally 54-66 min, 0\% Buffer B. Separated peaks were monitored at $254 \mathrm{~nm}$ and $280 \mathrm{~nm}$ wavelengths and collected in sterile tubes. The material was dried by evaporation and collected peaks were dissolved with $200 \mu \mathrm{L}$ of sterile Milli Q water and stored at $-20^{\circ} \mathrm{C}$ until further use. Compositions of the small molecules from the fractions were identified by HR-LCMS analysis and library search at IIT, Bombay SAIF Facility. HPLC was performed using a Hypersil Gold $(3 \mu) 100 * 2.1 \mathrm{~mm}$ column. The abundance of the molecules was estimated from the heights of the peaks. The drug-likeness behaviour (in accordance with Lipinski rule) of molecules present in CRACE was calculated using MolSoft Drug-likeness tool.

\section{Statistical analysis}

Statistical significance ( $p$ value) was calculated by two tailed unpaired t-test or one-way ANOVA or two-way ANOVA followed by Bonferroni post-test using Graph Pad Prism as mentioned in the figure legends.

\section{Results}

CRACE reduced lipid accumulation in differentiating 3T3L1 cells

Prior to test the effect of CRACE on adipocyte differentiation, nontoxic dose of the extract was determined by exposing 3T3-L1 cells to different doses of the extract for $24 \mathrm{~h}$ followed by MTT Assay (Fig. 1a). Up to $1000 \mu \mathrm{g} / \mathrm{mL}$ CRACE treatment was found to be nontoxic. The extract was found to be nontoxic to other tested cell types namely: mature adipocytes, muscle cells, hepatocytes and macrophages (Additional file 1: Figure S1). To determine the composition of CRACE, a preliminary phytochemical assay was performed, and presence of phenolics and tannins were detected in the extract. Total phenolic, flavonoid and tannin content were found to be $54.6 \mu \mathrm{g}$ Gallic acid equivalent, $26.5 \mu \mathrm{g}$ Quercetin equivalent, and $392.6 \mu \mathrm{g}$ equivalent of Tannic acid/mg, of the lyophilized CRACE respectively (Additional file 1: Table S1).

To test the effect of the extract on preadipocyte differentiation, 3T3-L1 cells were induced to differentiate in the presence of $300 \mu \mathrm{g} / \mathrm{mL}$ and $500 \mu \mathrm{g} / \mathrm{mL}$ CRACE. Oil Red $O$ staining of the intracellular lipids at 8 days of post induction revealed that, CRACE inhibited lipid accumulation in differentiating cells at both the doses, as confirmed by elution of Oil Red $\mathrm{O}$ from stained cells (Fig. $1 \mathrm{~b}$ and $\mathrm{c})$.

\section{CRACE modulated adipogenesis by modulating expression of key regulatory factors}

Transcription factor PPAR $\gamma$ has been at the center of the adipogenic program; required for expression and activation of factors necessary for lipid accumulation, insulin sensitivity as well as lipid metabolism [23, 24]. Among two PPARy isoforms, while PPARy1 is expressed in varying amounts in a wide array of cells, PPAR 2 expression is limited to only adipose tissue $[25,26]$. Estimation of PPAR $\gamma$ mRNAs and protein at the end of 8 days of differentiation showed that CRACE targeted both the isoforms of PPARy. Expression of both the PPAR $\gamma$ isoforms were suppressed during differentiation (Fig. 1d and e).

Differentiated adipocyte markers PLN1, FABP4, LPL, ATGL, GLUT4, and adiponectin, are downstream targets of PPAR $\gamma$, which govern the processes of lipid accumulation, glucose uptake, and lipid metabolism in differentiating adipocytes [23]. Analysis of these genes after 8 days of differentiation showed treatment with CRACE, downregulated all these PPAR $\gamma$ target genes, leading to inhibition of adipocyte differentiation (Fig. 1f). PLN1 protein content was also drastically reduced in CRACE treated differentiating 3T3-L1 cells (Fig. 1e).

\section{CRACE modulated expression of early and late adipogenic regulators}

To understand the mechanism of CRACE mediated PPAR $\gamma$ downregulation, mRNA expression of key transcription regulators of PPAR $\gamma$ gene were 
A

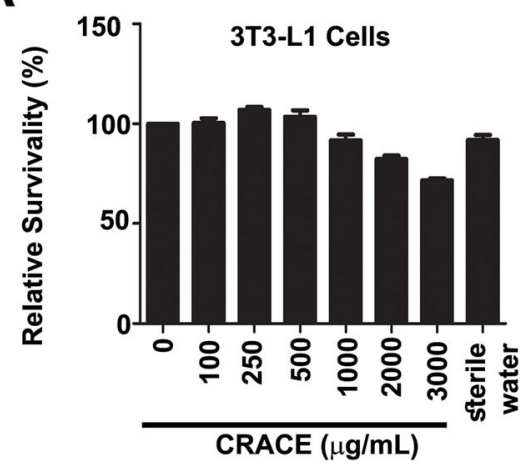

C

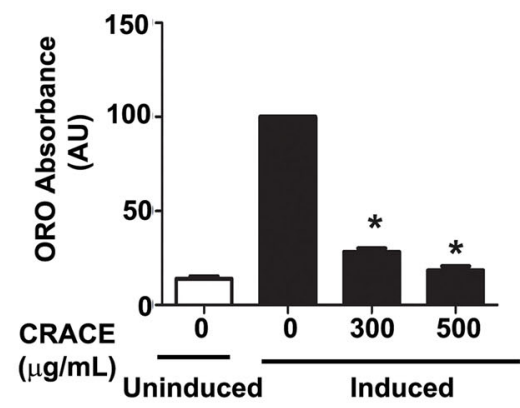

D

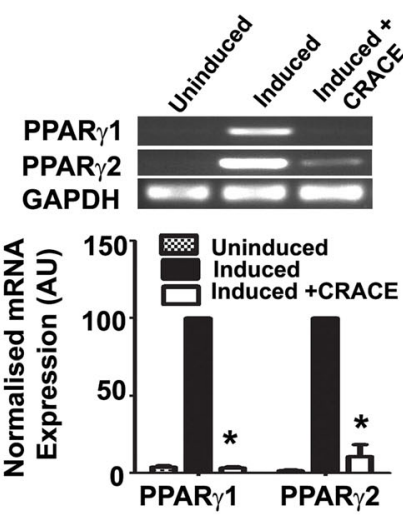

E

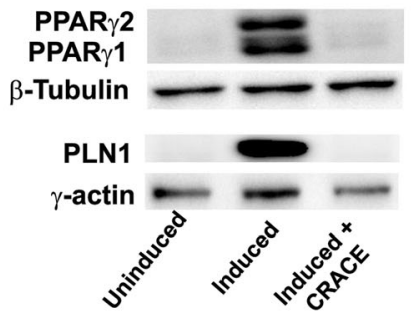

B $\quad$ CRACE treatment

DMEM (with high glucose) with $10 \%$ FBS and $1 \mathrm{X}$ antibiotic
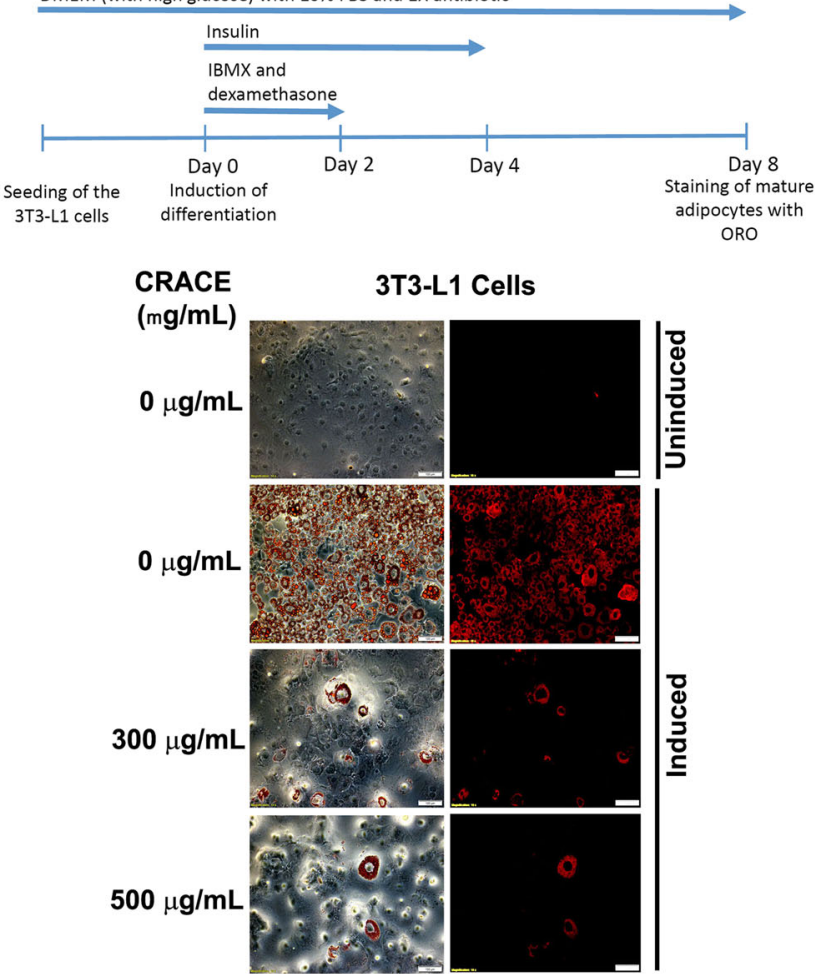

Phase Contrast Fluorescence
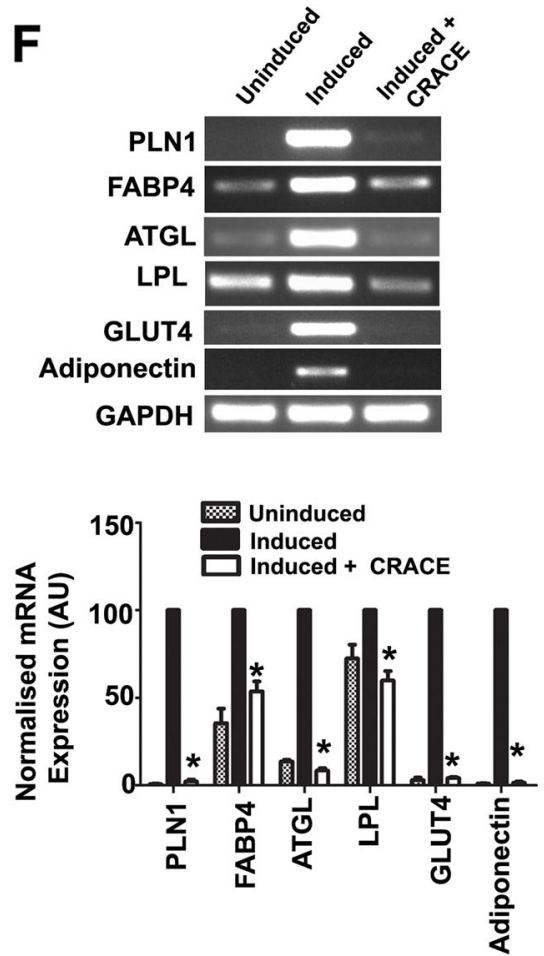

Fig. 1 (See legend on next page.) 
(See figure on previous page.)

Fig. 1 CRACE inhibited differentiation of 3T3-L1 preadipocytes. a. Percent survivability of 3T3-L1 cells as measured by MTT assay after exposure to different doses of CRACE for $24 \mathrm{~h}$. b. CRACE reduced lipid accumulation in differentiating 3T3-L1 cells. Top panel represents the design of the experiment. 3T3-L1 cells were induced with adipogenic cocktail \pm CRACE at the displayed doses for 4 days and subsequently kept in maintenance medium for an additional 4 days. Thereafter, ORO staining was performed. Images represent micrographs of ORO stained cells. Scale bar: $100 \mu \mathrm{m}$. c. Graph represents absorbance of extracted ORO from different groups of cells represented in panel b. d. Expression of PPARY1 and PPARY2 transcripts were reduced in CRACE treated group of induced 3T3-L1 cells. 3T3-L1 cells were induced for differentiation \pm CRACE (500 $\mu \mathrm{g} /$ $\mathrm{mL}$ equivalent) in the same way as described in panel $\mathbf{b}$. Gel images and bar diagram represent RT-PCR analysis of total RNA isolated after 8 days of induction. e. CRACE reduced PPARY1, PPARY2 and PLN1 protein level in differentiating 3T3-L1 cells are represented in panel a. Gel pictures represent western blot analysis of proteins isolated after 8 days of induction. f. CRACE reduced expression of PPARy target genes. Cell differentiation, and treatment is the same as in panel $\mathbf{d}$. Gel images and bar diagram represent RT-PCR analysis of PPARY regulated adipocyte factors: PLN1, FABP4, ATGL, LPL, GLUT4, and Adiponectin at 8 days after induction. All bars in the figure represent mean \pm SEM, $n=3$. $p$ values are from unpaired t-test. ${ }^{*}$ indicates $p<0.05$

analyzed at the early stage of differentiation $(2 \mathrm{~h}$ post induction). CEBP $\beta$ and CEBP $\delta$ expression occur very early during adipogenesis, and are the main inducers of PPAR $\gamma$ gene [27]. KLF5 is a pro-adipogenic molecule, which is expressed within an hour of adipogenic induction, enhancing the expression of PPAR 2 [28, 29]. At a downstream point, CEBP $\alpha$ is a key cross regulator of PPAR $\gamma$ expression, and these two genes regulate each other's expression [30]. Lipin1 is expressed at early point of differentiation and can increase PPAR $\gamma$ expression [31]. There are several negative regulators of adipogenesis like GATA2, GATA3, and KLF7 which need to be downregulated during preadipocyte differentiation. While at early point of adipogenesis GATA2 and GATA3 interact with CEBP $\beta$ and represses its expression [32], at a later stage GATA2 and GATA3, are reported to interact with CEBP $\alpha$ repressing PPAR $\gamma$ expression [33]. The other anti-adipogenic factor, KLF7, expression reduces PPAR $\gamma$, CEBP $\alpha$, FABP4, Adipsin etc. [34]. Expression analysis of these genes at the early stage of differentiation revealed that CRACE did not affect the expression of CEBP $\beta$, CEBP $\delta$, KLF5, GATA2 and GATA3 (Fig. 3a). However, it did affect the expression of a positive regulator Lipin1 and was a distinct negative regulator of KLF7 (Fig. 2a).

Gene expression analysis of adipogenic regulators at the later stage of differentiation (8 days post induction), revealed down regulation of key positive regulator of PPARY expression, CEBP $\alpha$, Lipin1 and other similar positive regulators like SREBP1c and FAS in the extract treated cells (Fig. 2b). SREBP1c, an integral component of lipid biosynthesis, is reported to activate PPAR $\gamma$ as well as provide ligands for PPAR $\gamma$ [35]; and is an up-regulator of GLUT4 expression in adipocytes [36]. FAS is another PPARy regulator reported to be under influence of SREBP1 activity [37-39]. The anti-adipogenic effect of the extract was further strengthened by the loss of activity of the repressor GATA2 in the treated cells with no concomitant variation in the negative regulator GATA3 expression (Fig. 2b).

\section{CRACE reduced fat accumulation in mature adipocytes}

To test if CRACE can reduce lipid content of mature adipocytes, completely differentiated 3T3-L1 adipocytes with equal initial lipid droplets, were treated with CRACE at different doses for 4 days. ORO staining of the cells showed CRACE could reduce lipid accumulation in mature adipocytes, at all the tested doses $(300 \mu \mathrm{g} / \mathrm{mL}$ and $500 \mu \mathrm{g} / \mathrm{mL})$ in a dose dependent manner (Fig. 3a). Quantification of lipid in treated and untreated cells by ORO extraction (Fig. 3b), and ORO fluorescence in microscopic images (Fig. 3c), showed $>50 \%$ drop in lipid accumulation in treated cells. Further comparison of lipid droplets in untreated vs CRACE $(500 \mu \mathrm{g} / \mathrm{mL}$ equivalent) treated mature adipocytes, showed that the average lipid droplet area was $14.2 \pm 3.6 \mu \mathrm{m}^{2}$ in untreated cells, and $4.4 \pm 0.7 \mu \mathrm{m}^{2}$ in treated cells (Fig. $3 \mathrm{~d}$ and $\mathrm{f}$ ). Moreover, number of lipid droplets > $20 \mu \mathrm{m}^{2}$ was significantly low in CRACE treated adipocytes, while the number of lipid droplets $<1 \mu \mathrm{m}^{2}$ was significantly low in CRACE untreated group of adipocytes, suggesting reduction in lipid accumulation in lipid droplets (Fig. 3e).

\section{CRACE reduced lipogenesis in 3T3-L1 adipocytes}

To test if reduced lipogenesis was the reason of reduced lipid accumulation in CRACE treated adipocytes, mRNA expression of factors related to these pathways were tested. PPAR $\gamma$, CEBP $\alpha$, FAS and SREBP1c are factors that regulate lipogenesis in differentiated 3T3-L1 cells $[40,41]$. While PPAR $y$ and CEBP $\alpha$ expression showed moderate decrease in CRACE treated cells, SREBP1c and FAS expression were decreased to a significant level (Fig. 4). While expression of some of the enzymes involved in lipid synthesis, and lipid droplet biogenesis, like ATP citrate lyase (ACLY) and Lipin1 were not affected by CRACE, the extract reduced expression of other important enzymes like Glycerol Phosphate Dehydrogenase 1 (GPD1) and FAS significantly (Fig. 

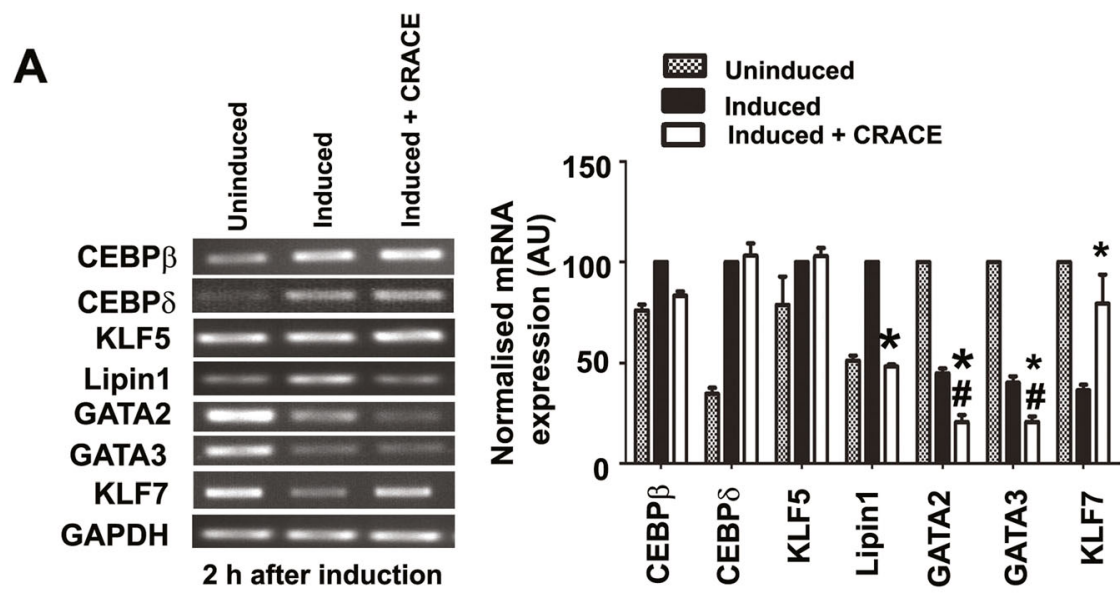

B

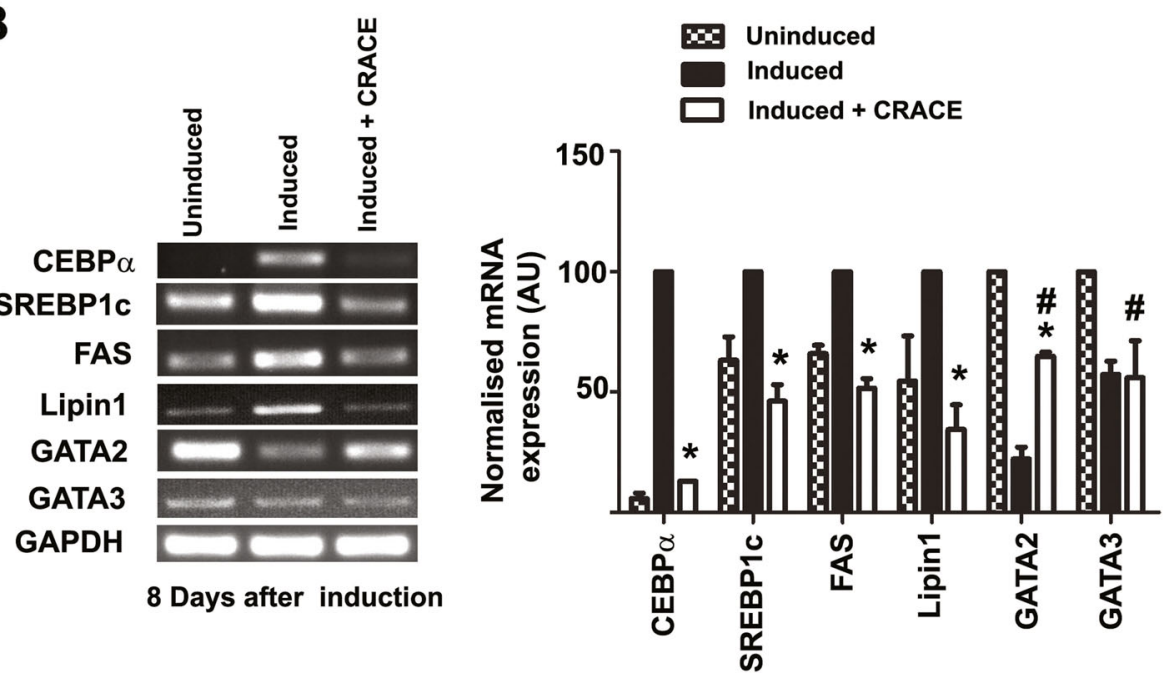

Fig. 2 CRACE modulated expression of pro- and anti-adipogenic regulators at early and late stage of adipogenesis. a. Gel images and bar diagram/diagrams represent RT-PCR analysis of early adipogenic regulators expressions in presence and absence of CRACE $(500 \mu \mathrm{g} / \mathrm{mL}$ equivalent); after $2 \mathrm{~h}$ of induction of adipogenesis in 3T3-L1 cells. b. Gel images and bar diagram represent RT-PCR analysis of adipogenic regulators expressions in presence and absence of CRACE $(500 \mu \mathrm{g} / \mathrm{mL}$ equivalent); at the late stage of adipogenesis (8 days post adipogenesis induction in 3T3-L1 cells). Bars represent mean \pm SEM. $n=3$. GAPDH mRNA expression was used as internal control. Unpaired t-test was performed to study the statistical significance. * represents $p<0.05$ for "Induced" vs "Induced + CRACE". \# represents $p<0.05$ for "Uninduced" vs. "Induced + CRACE"

4a). Expression of major glucose transporter GLUT4 was somewhat reduced by the extract. These observations suggested that lipogenesis may be affected to a certain extent in CRACE treated mature adipocytes.

CRACE induced lipolysis by inducing cAMP level and PKA activation

To test the extract's effect on lipolysis pathway, mRNA expression of several of the regulatory genes and enzymes were analysed (Fig. 4b). While major triacylglycerol (TAG) lipase ATGL expression was not changed by CRACE, its activator ABHD5 showed minor increased expression in CRACE treated cells. Expression of the major diacylglycerol
(DAG) lipase, HSL, was moderately decreased in CRACE treated cells. However, at the protein level, HSL activity depends on its own phosphorylation and the phosphorylation of PLN, which coats the lipid droplet DAG [42]. Phosphorylated HSL is brought to phospho-PLN-DAG by the FABP4 molecules [43]. The activity of ATGL also depends on PLN phosphorylation [44]. Expression of both, PLN and FABP4, were found to be unchanged in CRACE treated cells (Fig. 4b). Interestingly expression of G0S2 (G0/G1 Switch Gene 2), a negative regulator of ATGL activity, was decreased to a great extent upon CRACE treatment, implied a possible increase in ATGL activity (Fig. 4b) [45]. 


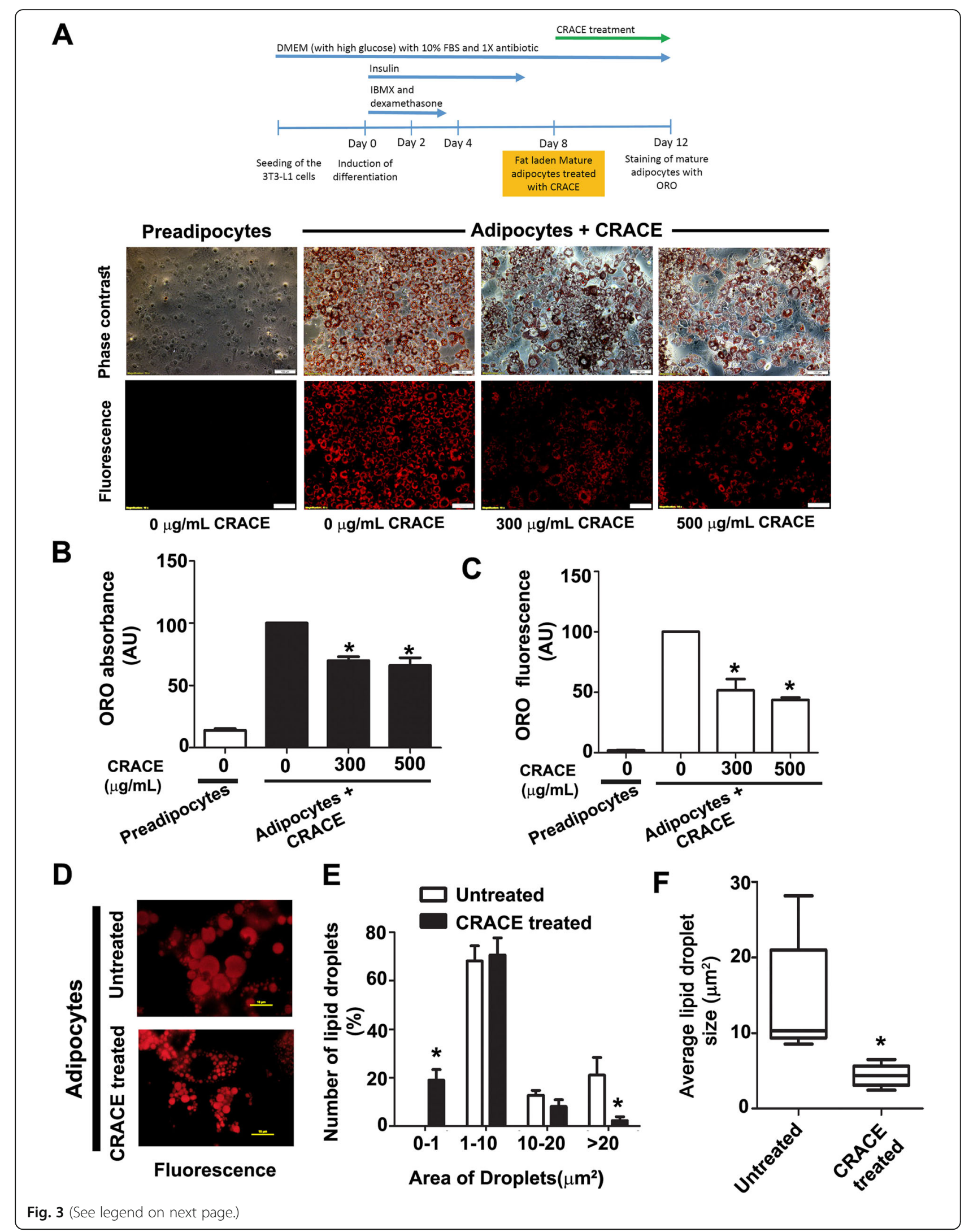




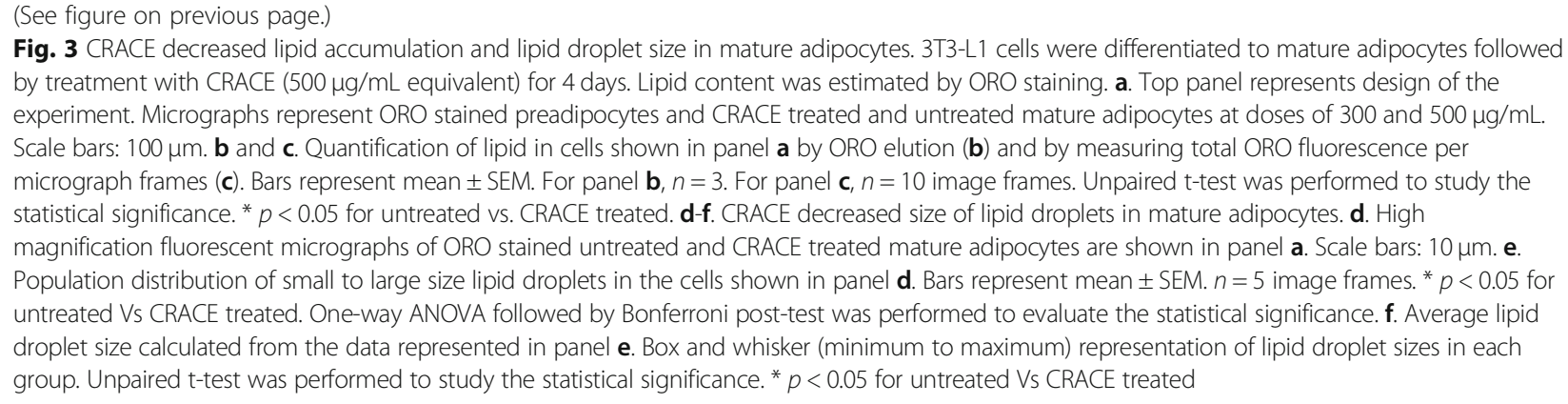

To test if there is any increase in lipase mediated lipolysis in CRACE treated cells, glycerol release was measured in treated and untreated cells (Fig. 4c). Treatment of fully differentiated fat cells with CRACE $(500 \mu \mathrm{g} / \mathrm{mL}$ equivalent) and known lipolysis inducer isoproterenol $(10 \mu \mathrm{M})$ for $3 \mathrm{~h}$ showed 2.4-fold increase in glycerol release in CRACE treated cells. This was comparable to isoproterenol treated cells which showed 2.8-fold increase in released glycerol. When the same assay was conducted with background lipolysis, balanced by treating cells with adenosine, followed by adenosine deaminase to remove adenosine mediated inhibition of lipolysis [46], similar induction of lipolysis in CRACE and isoproterenol treated cells were observed. Glycerol release was estimated to be 2.1 fold in CRACE and 2.3 fold in isoproterenol treated cells compared to untreated adipocytes $(\mathrm{A}+\mathrm{AD})$.

PKA dependent phosphorylation of HSL and PLN is essential for induction of lipolysis. While CRACE did not affect overall PLN1 level, it significantly increased pPLN1 level in adipocytes (Fig. 4d) indicating PKA activation. Interestingly CRACE decreased activating phosphorylation of Akt (S473) in adipocytes (Fig. 4d), which can lead to PKA activation by increasing cAMP accumulation. As PKA activation requires CAMP, its level was measured in CRACE treated 3T3-L1 preadipocytes. CRACE $(500 \mu \mathrm{g} / \mathrm{mL}$ equivalent $)$ treatment certainly increased cAMP level in 3T3-L1 preadipocytes > 2-fold within $15 \mathrm{~min}$ of treatment (Fig. 4e). A moderate decrease in expression of AdPLA2, which inhibited cAMP production and accumulation [33], was also observed in mature adipocytes, after treatment with CRACE $(500 \mu \mathrm{g} /$ $\mathrm{mL}$ equivalent) for 4 days (Fig. $4 \mathrm{~b}$ ). Finally effect of PKA inhibitor $\mathrm{H} 89$ on CRACE induced lipolysis was tested [47]. H89 could inhibit CRACE induced lipolysis significantly (Fig. 4f). However, isoproterenol induced lipolysis was not reduced to an equivalent level, as it is not dependent on PKA mediated activation of HSL and PLN1 [48]. The synergistic effect of CRACE and isoproterenol in lipolysis, was also lowered by $\mathrm{H} 89$ suggesting activation of PKA in presence of CRACE (Fig. 4f). All these observations suggested that CRACE induced lipolysis is due to increased cAMP level and activation of PKA.

Presence of potent anti-adipogenic factor 1a, 25dihydroxy vitamin D3 in most active fractions of CRACE To identify the component in CRACE which was responsible for its anti-adipogenic effect, $2 \mathrm{mg}$ lyophilized extract was fractionated by reverse-phase HPLC. Single or combinations of peaks were collected in 37 fractions. Each fraction was dried before dissolving with $200 \mu \mathrm{L}$ of water (Fig. 5a). Fractions were combined in 7 groups (CrA to CrG) (Fig. 5b) and were tested for their effect on adipocyte differentiation in the same manner as described in Fig. 1b and c. Cells were treated with grouped fractions in such a way that it equaled 6 and $9 \% \mathrm{v} / \mathrm{v}$ for each fraction. Considering both the doses, two groups $\mathrm{CrB}$ and $\mathrm{CrE}$, showed best inhibitory effect (Fig. 5c). Similarly, the grouped fractions were tested for their effect on adipocyte maturation process in the same manner as given in Fig. $3 a$ and $b$. In this assay only group CrB showed potent inhibitory effect (Fig. 5d). To identify the fraction/s in these groups which contained the antiadipogenic activities, individual fractions in these two groups were tested for their inhibitory effect on adipocyte differentiation. Fraction F10 and F29 appeared as active fractions in $\mathrm{CrB}$ and $\mathrm{CrE}$ respectively (Fig. 5e). These two fractions also showed equal inhibitory effect on adipocyte maturation process (Fig. 5f). To determine the composition of the small molecules in fractions F10 and F29, HR-LCMS analysis of the fractions were performed (Table 1). One common and abundant molecule with potent anti-adipogenic effect in both the fractions turn out to be $1 \alpha, 25$-dihydroxy vitamin D3, which is the biologically active form of vitamin D3 (Fig. 5g). Interestingly F10, the fraction which contains a higher percentage of the molecule, inhibited adipocyte differentiation more effectively. Apart from $1 \alpha, 25$-dihydroxy vitamin D3, both the fractions also contained significant amounts of a few other compounds. Many of these molecules including $1 \alpha, 25$-dihydroxy vitamin D3 are potential drug like molecules as suggested by their drug likeliness score (Table 1). 
A

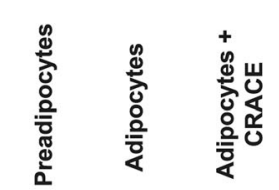
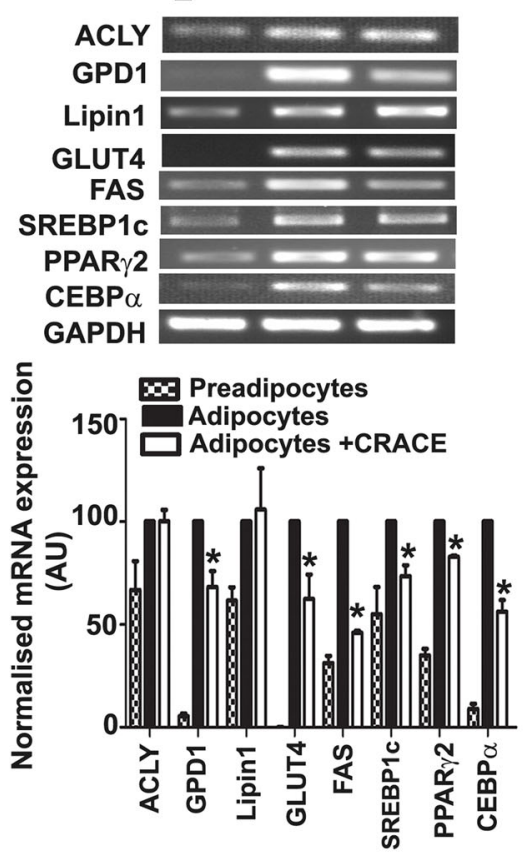

D
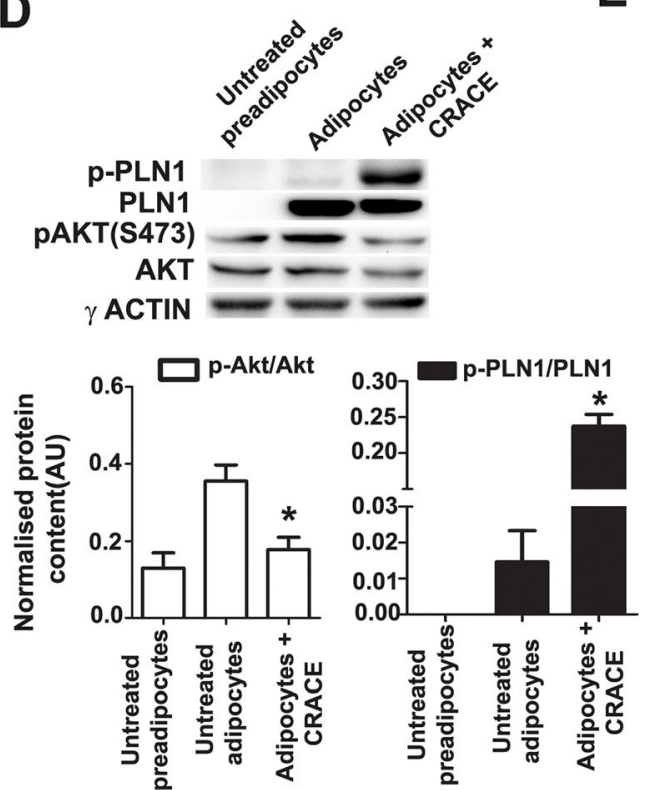

B

E

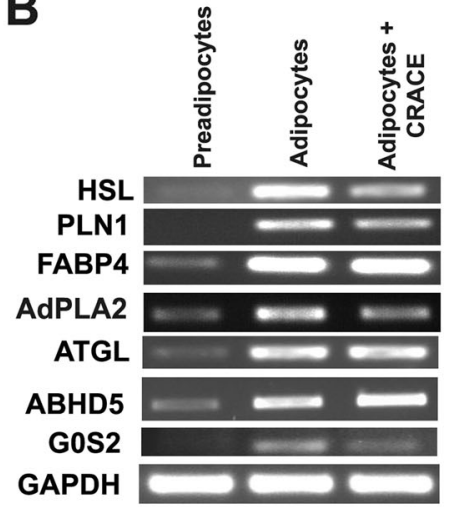

Dreadipocytes
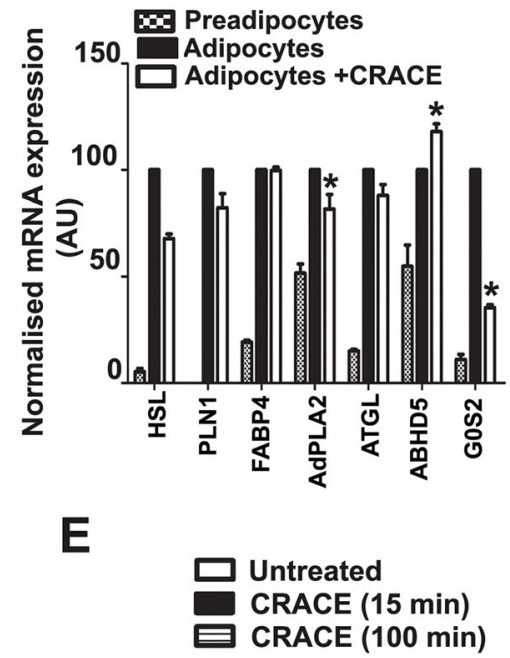

$\mathbf{F}$

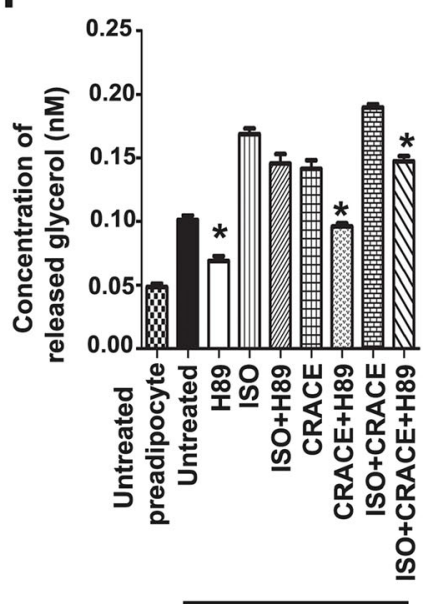

3T3-L1 adipocytes

Fig. 4 (See legend on next page.) 
(See figure on previous page.)

Fig. 4 CRACE reduced lipogenesis and induced lipolysis in mature 3T3-L1 adipocytes by increasing CAMP level and PKA activation. a. mRNA expression analysis of lipogenesis related genes in CRACE treated and untreated mature adipocytes. $\mathbf{b}$. mRNA expression analysis of major players of TAG lipolysis in CRACE treated and untreated mature adipocytes. In panel $\mathbf{a}$ and $\mathbf{b}$ mature adipocytes received CRACE (500 $\mu \mathrm{g} / \mathrm{mL}$ equivalent) for 4 days. Bars represent mean \pm SEM. $n=3 .{ }^{*} p<0.05$ for untreated vs. CRACE treated. c. Treatment with CRACE $(500 \mu \mathrm{g} / \mathrm{mL}$ equivalent) for $3 \mathrm{~h}$ increased lipolysis in mature 3T3-L1 adipocytes as measured by glycerol release. Isoproterenol (10 $\mu \mathrm{M})$ was used as positive control. CRACE also increased lipolysis in cells where basal lipolysis was normalised with $100 \mathrm{nM}$ adenosine (A) and $1 \mathrm{U} / \mathrm{mL}$ of adenosine deaminase (AD) treatment. Bars represent mean \pm SEM. $n=3$. * indicates $p<0.05$ for untreated vs. different treatments and \# indicates $p<0.05$ for $A+A D$ vs. A $+A D+$ different treatments. $\mathbf{d}$. CRACE increased PLN1 phosphorylation and decreased Akt phosphorylation (S473). Mature 3T3-L1 adipocytes were treated with CRACE $\left(500 \mathrm{\mu g} / \mathrm{mL}\right.$ equivalent) for $24 \mathrm{~h}$ followed by western blot analysis. Bars represent mean \pm SEM, $n=3 .{ }^{*} p<0.05$ for untreated vs. CRACE treated adipocytes. e. CRACE $(500 \mathrm{\mu g} / \mathrm{mL}$ equivalent) increased intracellular CAMP level in mature 3T3-L1 adipocytes. $0.5 \mathrm{mM}$ IBMX was added in all the cells for CAMP sustenance. Bars represent mean $\pm \mathrm{SEM}, n=3 .{ }^{*} p<0.05$ for untreated vs. treated adipocytes. f. CRACE stimulated lipolysis by PKA activation in mature 3T3-L1 adipocytes. Glycerol release induced in mature adipocytes by CRACE (500 $\mu \mathrm{g} / \mathrm{mL}$ equivalent) or isoproterenol in presence or absence of PKA inhibitor H89 was measured. CRACE induced lipolysis was significantly reduced by H89. Bars represent mean \pm SEM, $n=3 .{ }^{*} p<0.05$ for 'given treatments' vs. 'treatment + H89' (i.e. Untreated vs H89; CRACE vs CRACE + H89; ISO + CRACE vs ISO + CRACE + H89). Unpaired t-test (for panel $4 \mathbf{a}, 4 \mathbf{b}, 4 \mathbf{d}$ and $4 \mathbf{e}$ ) and one-way ANOVA followed by Bonferroni post-test (for panel $4 \mathbf{c}$ and $4 \mathbf{f}$ ) was performed to evaluate the statistical significance

To compare the activity of CRACE with pure $1 \alpha, 25-$ dihydroxy vitamin D3, different doses of each of the materials were tested on 3T3-L1 differentiation and maturation. In both the assays $500 \mu \mathrm{g} / \mathrm{mL}$ of CRACE treatment showed a fairly equivalent effect of $100 \mathrm{nM}$ (41.6 $\mathrm{ng} / \mathrm{mL}$ ) $1 \alpha, 25$-dihydroxy vitamin D3 treatment (Fig. 6a and $b$ ).

\section{Discussion}

Our quest for an anti-obesity therapeutic agent, lead us to investigate the medicinal herb $C$. roseus, which had well acclaimed and documented activity against cancer, diabetes and liver diseases. This study showed for the first time that the $C$. roseus aqueous crude extract (CRACE), prepared by a new method, was nontoxic to all tested cell types and had a potent anti-adipogenic effect (Fig. 1a, b and Additional file 1: Figure S1). The extract as whole, and the active fractions of the extract, displayed important dual activity; inhibition of 3T3-L1 preadipocyte differentiation, and the reduction of fat accumulation in differentiated mature adipocytes. While the extract reduced the expression of few important lipogenic genes, it concurrently, induced more than two-fold lipolysis, leading to reduced fat accumulation in mature adipocytes. Thus the extract can possibly modulate both, hypertrophy and hyperplasia, which are the predominant defects of adipocytes in obese conditions. The active fractions of the extract contain $1 \alpha$, 25-dihydroxy vitamin D3 as one of the major compounds (Fig. 5) along with significant amounts of a few other molecules. It is well documented that $1 \alpha, 25$-dihydroxy vitamin D3 is the biologically active form of vitamin D3 and has potent anti-adipogenic and pro-lipolytic activity on mouse cells [49-52]. However, the anti-adipogenic activity of vitamin D3 is currently inconclusive, as it exhibits rather contradictory effects on human and rat adipocytes [53-55]. A comparison of CRACE and pure $1 \alpha, 25-$ dihydroxy vitamin D3 activity suggests that $500 \mu \mathrm{g}$ of the extract may contain $\sim 40 \mathrm{ng}$ of $1 \alpha$, 25-dihydroxy vitamin D3.

Study on mechanism of CRACE activity indicated that it is a complex extract, exhibiting a range of activities. While CRACE treatment in differentiating preadipocytes has significantly inhibited expression of key adipogenic regulators PPAR $\gamma$ and CEBP $\alpha$; the expression of these genes in mature adipocytes were not equally inhibited. Expression of PPAR $\gamma$ target genes showed high correlation with PPAR $\gamma$ and CEBP $\alpha$ expression level in these two conditions. While PPAR $\gamma$ targets like PLN1, FABP4, LPL, ATGL, and GLUT4 were highly downregulated in differentiating adipocytes (Fig. 1f), many of these genes like PLN1, FABP4, ATGL, were not downregulated in mature adipocytes (Fig. 4). The PPARy target PLN1 is the lipid droplet coat protein, which is essential for lipid droplets formation and protection from lipases, when there are no catabolic signals [56]. Other PPARY targets like FABP4, ATGL, and LPL play major roles in lipid metabolism and lipid uptake [23, 43]. Thus inhibition of these genes in differentiating preadipocytes essentially inhibited lipid accumulation and differentiation of these cells into adipocytes.

On the other hand, CRACE mediated reduction of lipid accumulation in mature adipocytes occurred in a different way. CRACE reduced lipid accumulation by inducing lipolysis in mature adipocytes (Fig. 4). This was achieved by increased level of cAMP, leading to PKA activation. This was confirmed from the observation that treatment of cells with PKA inhibitor H89 inhibited CRACE induced lipolysis. Earlier studies showed that $1 \alpha, 25$-dihydroxy vitamin D3 treatment increases cAMP level and PKA activation 


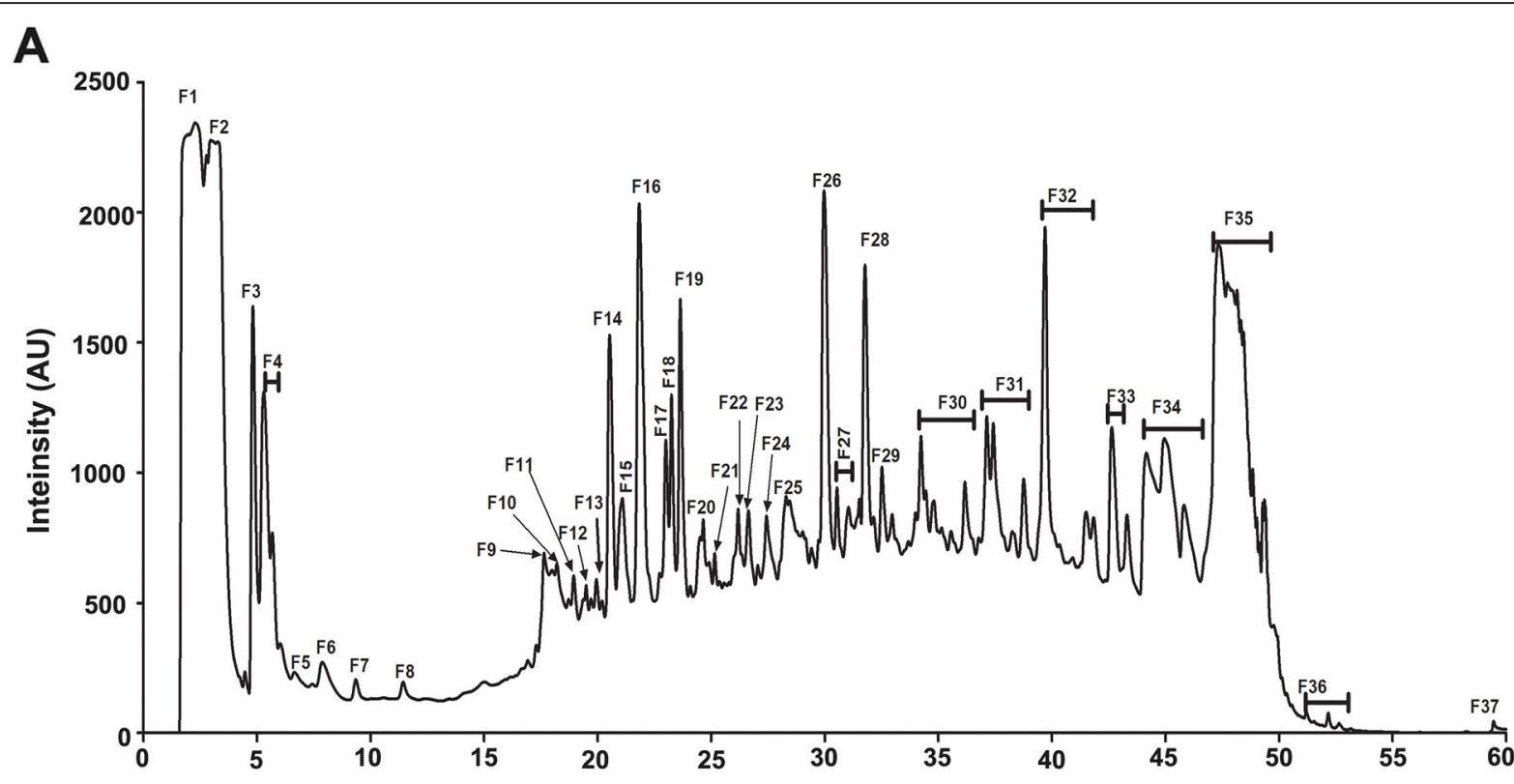

B

$$
\begin{array}{rr}
\begin{array}{c}
\text { Fraction } \\
\text { Code }
\end{array} & \begin{array}{r}
\text { Group } \\
\text { Code }
\end{array} \\
\hline \text { F1, F2, F3,F4,F5,F6 } & \text { CrA } \\
\text { F7,F8,F9,F10,F11,F12,F13 } & \text { CrB } \\
\text { F14,F15,F16,F17,F18,F19 } & \text { CrC } \\
\text { F20,F21,F22,F23,F24,F25 } & \text { CrD } \\
\text { F26,F27,F28,F29,F30 } & \text { CrE } \\
\text { F31,F32,F33,F34 } & \text { CrF } \\
\text { F35,F36,F37 } & \text { CrG }
\end{array}
$$

E

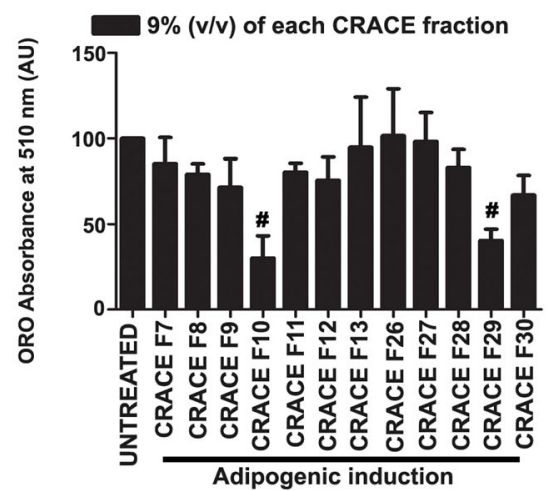

C

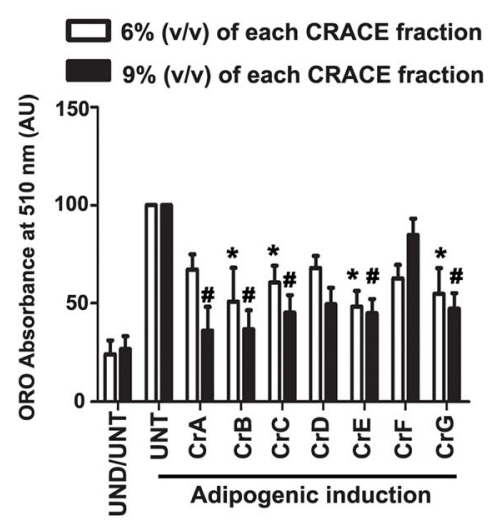

F

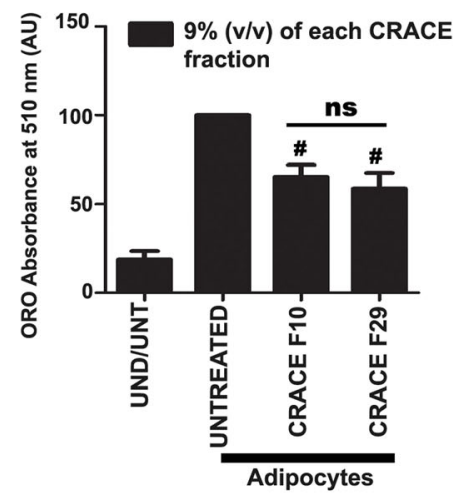

D

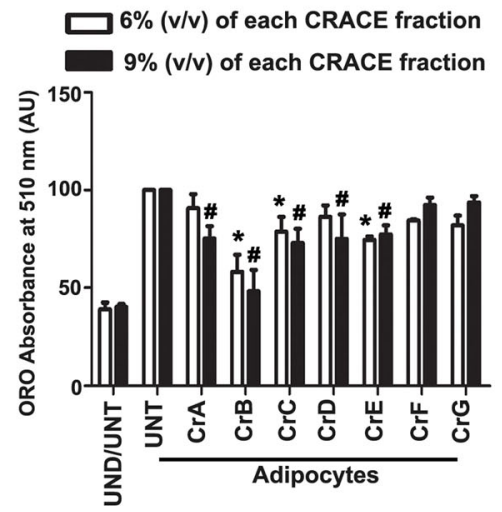

G

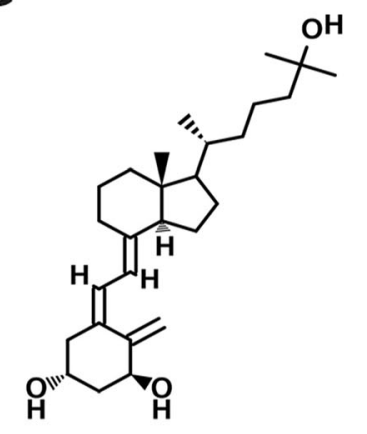

1 $\alpha, 25$ - Dihydroxy vitamin D3 
(See figure on previous page.)

Fig. 5 1a, 25-dihydroxy vitamin D3 was present in most active fractions in CRACE. a. HPLC Chromatogram of fractionation of CRACE. $200 \mu \mathrm{L}$ of $10 \mathrm{mg} /$ $\mathrm{mL}$ of CRACE was fractionated and later the dried fractions were dissolved again with $200 \mu \mathrm{L}$ of sterile milli $\mathrm{Q}$ water. $\mathbf{b}$. Fractions were grouped into 7 preparations named as $\mathrm{CrA}, \mathrm{CrB}, \mathrm{CrC}, \mathrm{CrD}, \mathrm{CrE}$, CrF and CrG. c. CRACE fraction groups CrB and CrE decreased 3 T3-L1 differentiation most efficiently. The cells received treatments with all the grouped CRACE fractions (at 6 and $9 \% \mathrm{v} / \mathrm{v}$ for each fraction) for first 4 days of adipogenic induction. Thereafter, the cells were allowed to be maintained for another 4 days before ORO staining was performed. Bars represent mean $\pm S E M, n=3$. Twoway ANOVA followed by Bonferroni post-test was performed to evaluate the statistical significance. ${ }^{*}$ indicates $p<0.05$ for induced-untreated (UNT) vs. induced- $6 \%$ treated. \# represents $p<0.05$ for induced-untreated (UNT) vs. induced- $9 \%$ treated groups. d. Fraction group CrB inhibited lipid accumulation in mature adipocytes most efficiently. Mature adipocytes with equal amount of lipid received treatment with all the grouped fractions (6 and $9 \% \mathrm{v} / \mathrm{v}$ ) for 4 days. Post treatment lipid content was measured by ORO staining. Bars represent mean \pm SEM, $n=3$. Two-way ANOVA followed by Bonferroni post-test was performed to evaluate the statistical significance. ${ }^{*}$ and \# indicate same as panel $\mathbf{c}$. e. All the fractions in group $\mathbf{b}$ and $\mathbf{e}$ were tested in the same manner as $\mathrm{C}$ at 9\% v/v for their effect on adipocyte differentiation. Fraction F10 and F29 appeared as active fractions in CrB and CrE respectively. Bars represent mean $\pm \mathrm{SEM}, n=3$. One-way ANOVA followed by Bonferroni post-test was performed to the evaluate statistical significance. \# indicates same as panel c. f. Fraction F10 and F29 were tested in the same manner as D at 9\% v/v for their effect on reduction of fat accumulation in mature adipocytes. Both the fractions reduced accumulated lipid in mature adipocytes. Bars represent mean $\pm \mathrm{SEM}, n=3$. One-way ANOVA followed by Bonferroni post-test was performed to evaluate the statistical significance. \# indicates same as panel c. g. 1a, 25-dihydroxy vitamin D3 is the common molecule which is present in F10 and F29 as major constituent

in muscle cells [57]. This suggests that observed effect of CRACE on CAMP/PKA is mediated by $1 \alpha$, 25-dihydroxy vitamin D3. Intriguingly CRACE reduced active Akt (p-Akt at S473) in mature adipocytes. Active Akt negatively regulates lipolysis by activating phosphodiesterase leading to reduced cAMP level [58]. Thus, decrease in p-Akt in CRACE treated cells might also have contributed in increasing the level of cAMP. Earlier studies suggested that $1 \alpha, 25$-dihydroxy vitamin D3 had no effect on Akt phosphorylation in 3T3-L1 cells in normal glucose condition [59]. This in turn suggests that, there may be compounds other than the $1 \alpha, 25$-dihydroxy vitamin D3, which are also part of active component of the extract. Consequently, the other molecules present in significant amounts in the active fractions, may assume this role. PKA dependent phosphorylation of major lipolytic enzyme HSL and its regulator PLN1 play a crucial positive regulatory role in the lipolytic pathway. PLN1 phosphorylation is also required for the activity of the first lipolytic enzyme ATGL which breaks down TAG. CRACE certainly stimulated a substantive PLN1 phosphorylation due to activation of PKA (Fig. 4d). CRACE did not affect the mRNA expression of the most of the lipolytic genes with exception of G0S2 which is a negative regulator of ATGL. CRACE has also reduced the expression of several lipogenic regulatory genes (SREBP1c, FAS), and lipogenic enzymes (FAS and GPD1) which contribute to de novo lipid synthesis and lipid droplet formation (Fig. 4a and b). Thus reduced lipid accumulation in mature adipocytes was a consequence of increased lipid breakdown and possibly reduced lipid production.

In differentiating preadipocytes, target of CRACE lies possibly upstream of PPAR $\gamma$. CRACE clearly did not affect the expression of most of the positive
(CEBP $\beta$, CEBP $\delta$ and KLF5), or the negative (GATA2 and GATA3) regulators of PPAR $\gamma$ gene expression, tested at the early stage of differentiation $(2 \mathrm{~h}$ post induction). While CRACE did affect the expression of a positive regulator Lipin1 and a negative regulator KLF7 (Fig. 2a), but it could not directly down regulate KLF7. The latter is known for its reduction of PPARY expression and is downregulated during induction of adipogenic differentiation [34]. On the other hand, the expression of Lipin1 which strengthens the expression of CEBP $\alpha$ and PPAR $\gamma$ [60], was inhibited by CRACE immediately after induction of differentiation, paving the path for inhibition of PPAR $\gamma$ and CEBP $\alpha$ in the later stage of differentiation (as tested after 8 days of induction) (Fig. 2b). Noticeably, Lipin1 was not inhibited by CRACE in mature adipocytes (Fig. 4a). This possibly explains why there was a very small decrease observed in PPAR $\gamma$ and CEBP $\alpha$ level in CRACE treated mature adipocytes (Fig. 4a). Other adipogenic genes like SREBP1c and FAS which are involved in lipid biosynthesis and are activators of PPAR $\gamma$, were also downregulated at the later stage of differentiation. Intriguingly, expression of GATA2 which was suppressed at the early stage of induction, seemed to be restored at the later stage in CRACE treated cells, possibly due to loss of other adipogenic signals (Fig. 2a and b). Earlier reports showed that anti-adipogenic action of $1 \alpha$, 25dihydroxy vitamin D3 is mediated by suppression of PPAR $\gamma, C E B P \alpha$, and SREBP1c gene expressions [61]. CRACE has also exhibited similar effects on these genes. $1 \alpha, 25$-dihydroxy vitamin D3 mediated suppression of preadipocyte differentiation, happens at the early stage of differentiation, just after mitotic clonal expansion phase, but it cannot inhibit differentiation at the later stage [61]. CRACE has also 
Table 1 List of abundant small molecules present in CRACE fraction F10 and F29 and their relative abundance observed by HRLCMS analysis

\begin{tabular}{|c|c|c|c|}
\hline Small Molecules & Molecular formula & Rel. Abundance (\%) & Drug Likeness Score \\
\hline \multicolumn{4}{|l|}{ CRACE F10 } \\
\hline 1a, 25 - dihydroxy Vitamin D3 & $\mathrm{C}_{27} \mathrm{H}_{44} \mathrm{O}_{3}$ & 34.4 & 0.47 \\
\hline Indole acrylic acid & $\mathrm{C}_{11} \mathrm{H}_{9} \mathrm{NO}_{2}$ & 12.3 & -1.75 \\
\hline Promazine sulfoxide & $\mathrm{C}_{17} \mathrm{H}_{20} \mathrm{~N}_{2} \mathrm{OS}$ & 9.3 & 0.98 \\
\hline Dehydroprotenone & $\mathrm{C}_{23} \mathrm{H}_{20} \mathrm{O}_{6}$ & 7.0 & -0.35 \\
\hline Grayanotoxin1 & $\mathrm{C}_{22} \mathrm{H}_{36} \mathrm{O}_{7}$ & 6.4 & -0.39 \\
\hline Ranitidine & $\mathrm{C}_{13} \mathrm{H}_{22} \mathrm{~N}_{4} \mathrm{O}_{3} \mathrm{~S}$ & 6.0 & 1.00 \\
\hline $\mathrm{N}$-(4-benzenesulfonamide) arachidonoyl amine & $\mathrm{C}_{26} \mathrm{H}_{38} \mathrm{~N}_{2} \mathrm{O}_{3} \mathrm{~S}$ & 4.9 & 0.08 \\
\hline 9,12-octadecadienal & $\mathrm{C}_{18} \mathrm{H}_{32} \mathrm{O}$ & 3.1 & -1.27 \\
\hline 7-aminonitrazepam & $\mathrm{C}_{15} \mathrm{H}_{13} \mathrm{~N}_{3} \mathrm{O}$ & 3.0 & 0.30 \\
\hline Griseofulvic acid & $\mathrm{C}_{16} \mathrm{H}_{15} \mathrm{ClO}_{6}$ & 2.9 & -0.06 \\
\hline N-(1R-methyl-2-hydroxy-ethyl)a, a, dimethyl arachidonoyl amine & $\mathrm{C}_{25} \mathrm{H}_{43} \mathrm{NO}_{2}$ & 2.8 & -0.48 \\
\hline Glucosamine & $\mathrm{C}_{6} \mathrm{H}_{13} \mathrm{NO}_{5}$ & 2.4 & 0.14 \\
\hline Mundoserone & $\mathrm{C}_{19} \mathrm{H}_{18} \mathrm{O}_{6}$ & 2.4 & -0.25 \\
\hline 18-bromo-17E-octadecenoic acid & $\mathrm{C}_{18} \mathrm{H}_{21} \mathrm{BrO}_{2}$ & 2.1 & 0.06 \\
\hline Methotimeprazine & $\mathrm{C}_{19} \mathrm{H}_{24} \mathrm{~N}_{2} \mathrm{OS}$ & 0.3 & 1.15 \\
\hline \multicolumn{4}{|l|}{ CRACE F29 } \\
\hline 1a, 25- dihydroxy Vitamin D3 & $\mathrm{C}_{27} \mathrm{H}_{44} \mathrm{O}_{3}$ & 20.7 & 0.47 \\
\hline 5- $\beta$-androstan-3a-ol-17-one sulfate & $\mathrm{C}_{19} \mathrm{H}_{30} \mathrm{O}_{5} \mathrm{~S}$ & 20.5 & 0.38 \\
\hline Proglumide & $\mathrm{C}_{18} \mathrm{H}_{26} \mathrm{~N}_{2} \mathrm{O}_{4}$ & 11.9 & 0.80 \\
\hline Grayanotoxin 1 & $\mathrm{C}_{22} \mathrm{H}_{36} \mathrm{O}_{7}$ & 5.4 & -0.39 \\
\hline Promazine sulfoxide & $\mathrm{C}_{17} \mathrm{H}_{20} \mathrm{~N}_{2} \mathrm{OS}$ & 4.8 & 0.98 \\
\hline Estradiol diacetate & $\mathrm{C}_{22} \mathrm{H}_{28} \mathrm{O}_{4}$ & 4.3 & 0.79 \\
\hline 6,3'-dimethoxyflavone & $\mathrm{C}_{17} \mathrm{H}_{14} \mathrm{O}_{4}$ & 3.9 & 0.47 \\
\hline Ergoline-8-methanol,10-methoxy-6-methyl-(8b) & $\mathrm{C}_{17} \mathrm{H}_{22} \mathrm{~N}_{2} \mathrm{O}_{2}$ & 3.8 & -0.28 \\
\hline $\mathrm{N}$-(4-benzenesulfonamide) arachidonoyl amine & $\mathrm{C}_{26} \mathrm{H}_{38} \mathrm{~N}_{2} \mathrm{O}_{3} \mathrm{~S}$ & 3.2 & 0.08 \\
\hline Desmethyl trimipramine glucuronide & $\mathrm{C}_{25} \mathrm{H}_{32} \mathrm{~N}_{2} \mathrm{O}_{6}$ & 2.9 & 1.07 \\
\hline 12a hydroxyl-5-deoxyhdromunduserone & $\mathrm{C}_{19} \mathrm{H}_{18} \mathrm{O}_{6}$ & 2.6 & -0.25 \\
\hline Ranitidine & $\mathrm{C}_{13} \mathrm{H}_{22} \mathrm{~N}_{4} \mathrm{O}_{3} \mathrm{~S}$ & 2.5 & 1.00 \\
\hline N-(5-hydroxy-pentyl)arachidonoyl amine & $\mathrm{C}_{25} \mathrm{H}_{43} \mathrm{NO}_{2}$ & 2.3 & -0.36 \\
\hline Norethynodrel & $\mathrm{C}_{20} \mathrm{H}_{26} \mathrm{O}_{2}$ & 2.2 & 1.24 \\
\hline Praziquantel & $\mathrm{C}_{19} \mathrm{H}_{24} \mathrm{~N}_{2} \mathrm{O}_{2}$ & 2.2 & 0.95 \\
\hline 9,12-octadecadienal & $\mathrm{C}_{18} \mathrm{H}_{32} \mathrm{O}$ & 2.1 & -1.27 \\
\hline 11-amino undecanoic acid & $\mathrm{C}_{11} \mathrm{H}_{23} \mathrm{NO}_{2}$ & 1.7 & 0.61 \\
\hline Amorolfine & $\mathrm{C}_{21} \mathrm{H}_{35} \mathrm{NO}$ & 1.6 & 0.93 \\
\hline Mebhydrolin & $\mathrm{C}_{19} \mathrm{H}_{20} \mathrm{~N}_{2}$ & 1.3 & 1.29 \\
\hline
\end{tabular}

modulated early gene expressions during preadipocyte differentiation.

\section{Conclusions}

In conclusion, CRACE and its active fractions can potentially modulate adipose tissue by a two prong method; inhibiting adipogenesis as well as reducing lipid accumulation in mature adipocytes. Earlier reports on mice, indicated inhibition of adipogenesis and lipogenesis; consequently the induction of lipolysis can improve obesity and systemic glucose homeostasis [8]. CRACE has many of these properties and the additional, yet to fully explored potential, for an excellent anti-obesity therapeutic agent. Such 


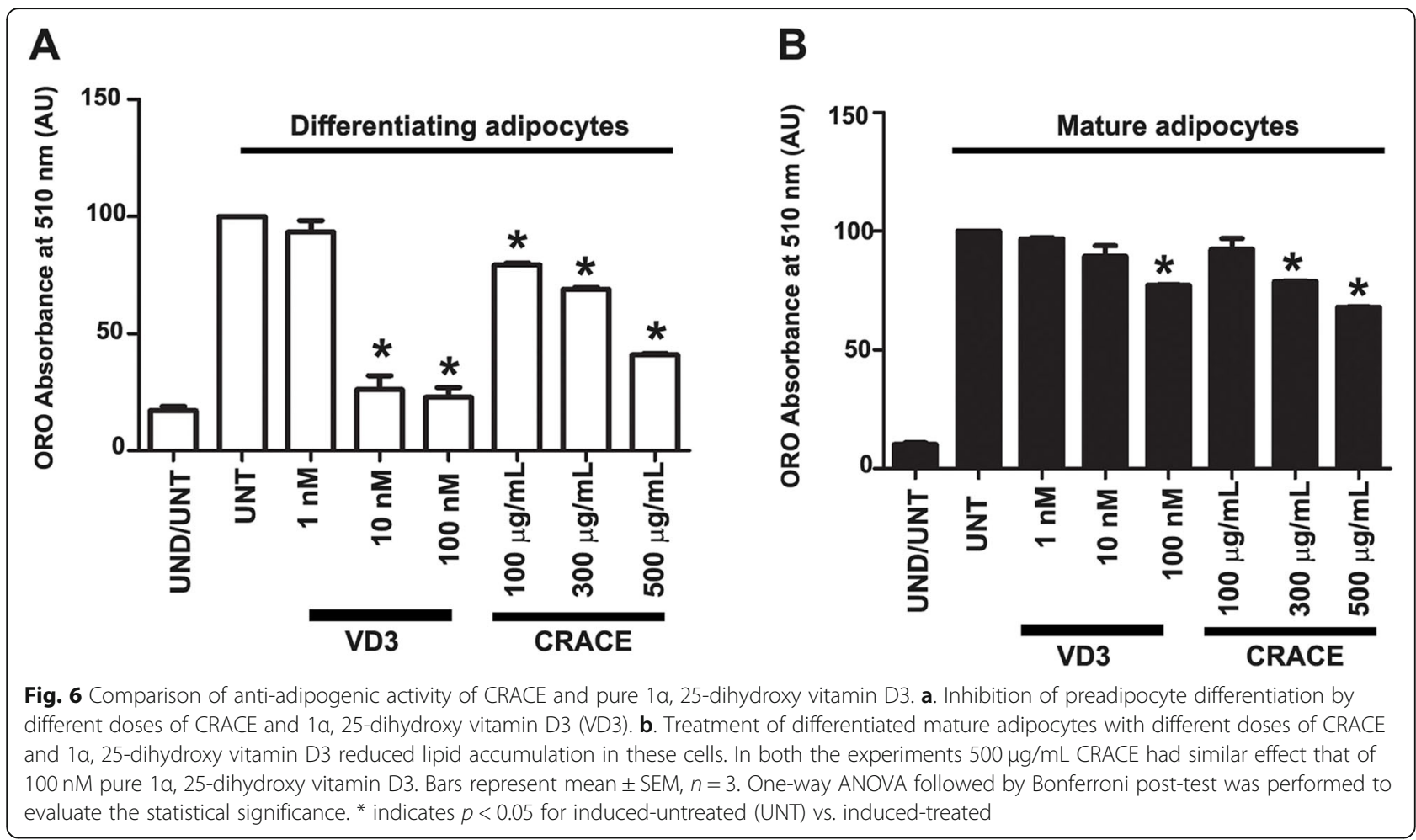

versatile activity of CRACE can be due to presence of $1 \alpha, 25$-dihydroxy vitamin D3 which may work along with other compounds of the active fractions to bring about anti-adipogenic effects [49]. This work invites future initiatives into understanding the active fractions of the extract and their effect in vivo.

\section{Supplementary information}

Supplementary information accompanies this paper at https://doi.org/10. 1186/s12906-019-2754-7.

Additional file 1: Table S1. Phytochemical analysis of CRACE. Table S2. Primer sequences. Figure S1. CRACE was non-cytotoxic to a number of tested cells at tested doses.

\section{Abbreviations}

2-NBDG: (2-(N-(7-Nitrobenz-2-oxa-1,3-diazol-4-y))Amino)-2-Deoxyglucose); A + AD: Adenosine + Adenosine deaminase; ABHD5: $/ / \beta$ hydrolase domain containing protein 5; ACLY: ATP citrate lyase; AdPLA2Adipose phospholipase A2; ATGL: Adipose triglyceride lipase; C/EBP: CAAT enhancer binding protein; DAG: Diacyl glycerol; FABP4: Fatty acid binding protein 4; FAS: Fatty acid synthase; GOS2: G0/G1 Switch gene2; GAPDH: Glyceraldehyde 3-phosphate dehydrogenase; GATA2/3: GATA binding protein 2//3; GLUT4: Glucose transporter 4; GPD: Glycerol 3-phosphate dehydrogenase; HSL: Hormone sensitive lipase; IBMX: 3-Isobutyl-1-methyl xanthine; ISO: Isoproterenol; KLF: Kruppel like factor; LPL: Lipoprotein lipase; ORO: Oil red O;

PLN.1: Perilipin 1; PPARY: Peroxisome proliferative activated receptor $\gamma$; SREBP1c: Sterol regulatory element binding protein 1c; TAG: Triacylglycerol

\section{Acknowledgements}

We thank Mrs. Munmi Majumder of Tezpur University for her help in identification of the plant. We thank BSI Shillong for identification of the plant. We thank IIT-Bombay SAIF facility for HR-LCMS analysis of the plant extract. We thank Dr. Gaurangi Maitra for careful editing of the text. AKB is supported by DBT-India (Fellow \# DBT/2014/TZU/146). AS is supported by fellowship from SERB-India (grant \# EMR/2016/004001). We are thankful to funding agencies (UGC-SAP, DST FIST, DBT Strengthening, DBT Hub, DBT-BIF) for their support to Department of MBBT, TU., where this work was carried out.

Authors' contributions

AKB designed and performed majority of the experiments, analysed, interpreted the data, and has written the manuscript. AS performed some of the gene expression studied in adipocytes and analysed the data. RY and RD participated in fractionation of the extract by HPLC. VSKM participated in the statistical analysis of the data. SS designed the experiments, analysed and interpreted the data, and has conceptualized/ written the manuscript. All authors read and approved the final manuscript.

\section{Funding}

Work presented in this manuscript is not funded by any specific sanctioned project. Laboratory of SS is currently funded by multiple grants from SERB, India.

Availability of data and materials

All data generated or analysed during this study are included in this published article and its supplementary information files.

Ethics approval and consent to participate

Not applicable.

\section{Consent for publication}

Not applicable.

\section{Competing interests}

The authors declare that they have no competing interest.

\section{Author details}

'Department of Molecular Biology and Biotechnology, Tezpur University, Napaam, Tezpur, Assam 784028, India. 'Department of Biotechnology, National Institute of Technology, Durgapur, West Bengal 713209, India. 
Received: 16 May 2019 Accepted: 14 November 2019 Published online: 29 November 2019

\section{References}

1. Kopelman PG. Obesity as a medical problem. Nature. 2000;404(6778):635-43.

2. James WPT. Obesity: a global public health challenge. Clin Chem. 2018; 64(1):24-9.

3. Sarjeant K, Stephens JM. Adipogenesis. Cold Spring Harb Perspect Biol. 2012:4(9):a008417.

4. Lee J-E, Schmidt H, Lai B, Ge K. Transcriptional and epigenomic regulation of adipogenesis. Mol Cell Biol. 2019;39(11):e00601-18.

5. Xu H, Barnes GT, Yang Q, Tan G, Yang D, Chou CJ, Sole J, Nichols A, Ross JS, Tartaglia LA. Chronic inflammation in fat plays a crucial role in the development of obesity-related insulin resistance. J Clin Invest. 2003;112(12): 1821-30.

6. Weisberg SP, McCann D, Desai M, Rosenbaum M, Leibel RL, Ferrante AW. Obesity is associated with macrophage accumulation in adipose tissue. J Clin Invest. 2003;112(12):1796-808.

7. Pal D, Dasgupta S, Kundu R, Maitra S, Das G, Mukhopadhyay S, Ray S, Majumdar SS, Bhattacharya S. Fetuin-A acts as an endogenous ligand of TLR4 to promote lipid-induced insulin resistance. Nat Med. 2012;18(8):nm): 2851.

8. Seo JB, Choe SS, Jeong HW, Park SW, Shin HJ, Choi SM, Park JY, Choi EW, Kim JB, Seen DS. Anti-obesity effects of Lysimachia foenum-graecum characterized by decreased adipogenesis and regulated lipid metabolism. Exp Mol Med. 2011:43(4):205.

9. Patel $Y$, Vadgama $V$, Baxi S, Tripathi B. Evaluation of hypolipidemic activity of leaf juice of Catharanthus roseus (Linn.) G. Donn. In Guinea pigs. Acta Pol Pharm. 2011;68(6):927-35.

10. Akhtar MA, Rashid M, Wahed MII, Islam MR, Shaheen SM, Islam MA, Amran MS, Ahmed M. Comparison of long-term antihyperglycemic and hypolipidemic effects between Coccinia cordifolia (Linn.) and Catharanthus roseus (Linn.) in alloxan-induced diabetic rats. Res J Medicine \& Med Sci. 2007;2(1):29-34.

11. Nammi S, Boini MK, Lodagala SD, Behara RBS. The juice of fresh leaves of Catharanthus roseus Linn. reduces blood glucose in normal and alloxan diabetic rabbits. BMC Complement Altern Med. 2003;3(1):4

12. Morrison EYSA, West ME. A preliminary study of the effects of some West Indian medicinal plants on blood sugar levels in the dog. West Indian Med J. 1982;31(4):194-7.

13. De Mello JF. Plants in traditional medicine in Brazil. J Ethnopharmacol. 1980; 2(1):49-55.

14. Patel D, Kumar R, Laloo D, Hemalatha S. Natural medicines from plant source used for therapy of diabetes mellitus: an overview of its pharmacological aspects. Asian Pac J Trop Dis. 2012;2(3):239-50

15. van de Venter M, Roux S, Bungu LC, Louw J, Crouch NR, Grace OM, Maharaj $V$, Pillay P, Sewnarian P, Bhagwandin N. Antidiabetic screening and scoring of 11 plants traditionally used in South Africa. J Ethnopharmacol. 2008; 119(1):81-6

16. Patel S, Gheewala N, Suthar A, Shah A. In-vitro cytotoxicity activity of Solanum nigrum extract against Hela cell line and Vero cell line. Int J Pharm Pharm Sci. 2009:1(1):38-46.

17. Borah AK, Kuri PR, Singh A, Saha S. Anti-adipogenic effect of Terminalia chebula fruit aqueous extract in 3T3-L1 preadipocytes. Pharmacogn Mag. 2019;15(64):197.

18. Madsen L, Petersen RK, Sørensen MB, Jørgensen C, Hallenborg P, Pridal L, Fleckner J, Ez-Zoubir A, Krieg P, Furstenberger G. Adipocyte differentiation of 3T3-L1 preadipocytes is dependent on lipoxygenase activity during the initial stages of the differentiation process. Biochem J. 2003;375(3):539-49.

19. Singh A, Borah AK, Deka K, Gogoi AP, Verma K, Barah P, Saha S. Arginylation regulates adipogenesis by regulating expression of PPARY at transcript and protein level. Biochim Biophys Acta Mol Cell Biol Lipids. 2019;1864(4):596607.

20. Mehlem A, Hagberg CE, Muhl L, Eriksson U, Falkevall A. Imaging of neutral lipids by oil red $\mathrm{O}$ for analyzing the metabolic status in health and disease. Nat Protoc. 2013;8(6):1149-54.

21. Lee M-J, Fried SK. Optimal protocol for the differentiation and metabolic analysis of human adipose stromal cells. Methods Enzymol. 2014;538:49.

22. Karumi $Y$, Onyeyili $P$, Ogugbuaja $V$. Identification of active principles of $M$. balsamina (balsam apple) leaf extract. J Med Sci. 2004;4(3):179-82.
23. Gregoire FM, Smas CM, Sul HS. Understanding adipocyte differentiation. Physiol Rev. 1998;78(3):783-809.

24. Tontonoz P, Hu E, Spiegelman BM. Stimulation of adipogenesis in fibroblasts by PPARY2, a lipid-activated transcription factor. Cell. 1994;79(7):1147-56.

25. Auboeuf D, Rieusset J, Fajas L, Vallier P, Frering V, Riou JP, Staels B, Auwerx $J$, Laville M, Vidal $H$. Tissue distribution and quantification of the expression of mRNAs of peroxisome proliferator-activated receptors and liver $X$ receptor-a in humans: no alteration in adipose tissue of obese and NIDDM patients. Diabetes. 1997;46(8):1319-27.

26. Medina-Gomez G, Gray SL, Yetukuri L, Shimomura K, Virtue S, Campbell M, Curtis RK, Jimenez-Linan M, Blount M, Yeo GS. PPAR gamma 2 prevents lipotoxicity by controlling adipose tissue expandability and peripheral lipid metabolism. PLoS Genet. 2007:3(4):e64.

27. Darlington GJ, Ross SE, MacDougald OA. The role of C/EBP genes in adipocyte differentiation. J Biol Chem. 1998:273(46):30057-60.

28. Wu Z, Wang S. Role of kruppel-like transcription factors in adipogenesis. Dev Biol. 2013:373(2):235-43.

29. Oishi Y, Manabe I, Tobe K, Tsushima K, Shindo T, Fujiu K, Nishimura G, Maemura K, Yamauchi T, Kubota N. Krüppel-like transcription factor KLF5 is a key regulator of adipocyte differentiation. Cell Metab. 2005;1(1):27-39.

30. Cristancho $A G$, Lazar MA. Forming functional fat: a growing understanding of adipocyte differentiation. Nat Rev Mol Cell Biol. 2011;12(11):722-34.

31. Kim HE, Bae E. Jeong D-y, Kim M-J, Jin W-J, Park S-W, Han G-S, Carman GM, Koh E, Kim K-S: Lipin1 regulates PPARy transcriptional activity. Biochem J. 2013;453(1):49-60.

32. Farmer SR. Transcriptional control of adipocyte formation. Cell Metab. 2006; 4(4):263-73.

33. Jaworski K, Ahmadian M, Duncan RE, Sarkadi-Nagy E, Varady KA, Hellerstein MK, Lee H-Y, Samuel VT, Shulman GI, Kim K-H. AdPLA ablation increases lipolysis and prevents obesity induced by high-fat feeding or leptin deficiency. Nat Med. 2009;15(2):159-68.

34. Kawamura Y, Tanaka Y, Kawamori R, Maeda S. Overexpression of Kruppellike factor 7 regulates adipocytokine gene expressions in human adipocytes and inhibits glucose-induced insulin secretion in pancreatic $\beta$-cell line. Mol Endocrinol. 2006;20(4):844-56.

35. Payne VA, Au W-S, Lowe CE, Rahman SM, Friedman JE, O'Rahilly S, Rochford JJ. C/EBP transcription factors regulate SREBP1C gene expression during adipogenesis. Biochem J. 2010:425(1):215-24.

36. Im S-S, Kwon S-K, Kang S-Y, Kim T-H, Kim H-I, Hur M-W, Kim K-S, Ahn Y-H. Regulation of GLUT4 gene expression by SREBP-1C in adipocytes. Biochem J. 2006:399(1):131-9.

37. Lodhi IJ, Yin L, Jensen-Urstad AP, Funai K, Coleman T, Baird JH, El Ramahi MK, Razani B, Song H, Fu-Hsu F. Inhibiting adipose tissue lipogenesis reprograms thermogenesis and PPARy activation to decrease diet-induced obesity. Cell Metab. 2012;16(2):189-201.

38. Griffin MJ, Sul HS. Insulin regulation of fatty acid synthase gene transcription: roles of USF and SREBP-1C. IUBMB Life. 2004;56(10):595-600.

39. Oem J-K, Jackel-Cram C, Li Y-P, Zhou Y, Zhong J, Shimano H, Babiuk LA, Liu Q. Activation of sterol regulatory element-binding protein $1 \mathrm{c}$ and fatty acid synthase transcription by hepatitis C virus non-structural protein 2. J Gen Virol. 2008:89(5):1225-30.

40. Schultz JR, Tu H, Luk A, Repa JJ, Medina JC, Li L, Schwendner S, Wang S, Thoolen M, Mangelsdorf DJ. Role of LXRs in control of lipogenesis. Genes Dev. 2000;14(22):2831-8.

41. Joseph SB, Laffitte BA, Patel PH, Watson MA, Matsukuma KE, Walczak R, Collins JL, Osborne TF, Tontonoz P. Direct and indirect mechanisms for regulation of fatty acid synthase gene expression by liver $X$ receptors. J Biol Chem. 2002;277(13):11019-25.

42. Londos C, Brasaemle DL, Schultz CJ, ADLER-WAILES DC, Levin DM, Kimmel AR, Rondinone CM. On the control of lipolysis in adipocytes. Ann N Y Acad Sci. 1999;892(1):155-68.

43. Nielsen TS, Jessen N, Jørgensen JOL, Møller N, Lund S. Dissecting adipose tissue lipolysis: molecular regulation and implications for metabolic disease. J Mol Endocrinol. 2014:52(3):R199-222.

44. Yamaguchi T, Omatsu N, Matsushita S, Osumi T. CGI-58 interacts with perilipin and is localized to lipid droplets. Possible involvement of CGI-58 mislocalization in chanarin-dorfman syndrome. J Biol Chem. 2004;279(29): 30490-7.

45. Yang X, Lu X, Lombès M, Rha GB, Chi Y-I, Guerin TM, Smart EJ, Liu J. The G 0/G 1 switch gene 2 regulates adipose lipolysis through association with adipose triglyceride lipase. Cell Metab. 2010;11(3):194-205. 
46. Honnor R, Dhillon G, Londos C. CAMP-dependent protein kinase and lipolysis in rat adipocytes. I. Cell preparation, manipulation, and predictability in behavior. J Biol Chem. 1985;260(28):15122-9.

47. Fernández-Galilea M, Pérez-Matute P, Prieto-Hontoria PL, Martinez JA, Moreno-Aliaga MJ. Effects of lipoic acid on lipolysis in 3T3-L1 adipocytes. J Lipid Res. 2012;53(11):2296-306.

48. Morimoto C, Tsujita T, Sumida M, Okuda H. Substrate-dependent lipolysis induced by isoproterenol. Biochem Biophys Res Commun. 2000;274(3):631-4.

49. Chang E, Kim Y. Vitamin D decreases adipocyte lipid storage and increases NAD-SIRT1 pathway in 3T3-L1 adipocytes. Nutrition. 2016;32(6):702-8.

50. Wilmanski T, Buhman K, Donkin SS, Burgess JR, Teegarden D. 1a, 25dihydroxyvitamin $D$ inhibits de novo fatty acid synthesis and lipid accumulation in metastatic breast cancer cells through down-regulation of pyruvate carboxylase. J Nutr Biochem. 2017;40:194-200.

51. Blumberg JM, Tzameli I, Astapova I, Lam FS, Flier JS, Hollenberg AN. Complex role of the vitamin $\mathrm{D}$ receptor and its ligand in adipogenesis in 3T3-L1 cells. J Biol Chem. 2006;281(16):11205-13.

52. Dave S, Kaur NJ, Nanduri R, Dkhar HK, Kumar A, Gupta P. Inhibition of adipogenesis and induction of apoptosis and lipolysis by stem bromelain in 3T3-L1 adipocytes. PLoS One. 2012;7(1):e30831.

53. Nimitphong H, Holick MF, Fried SK, Lee M-J. 25-hydroxyvitamin D3 and 1, 25-dihydroxyvitamin D3 promote the differentiation of human subcutaneous preadipocytes. PLoS One. 2012;7(12):e52171.

54. Felicidade I, Sartori D, Coort SL, Semprebon SC, Niwa AM, D'Epiro GFR, Biazi Bl, Marques LA, Evelo CT, Mantovani MS. Role of 1a, 25-Dihydroxyvitamin D3 in adipogenesis of SGBS cells: new insights into human preadipocyte proliferation. Cell Physiol Biochem. 2018;48(1):407-18.

55. Bellows C, Wang Y, Heersche J, Aubin J. 1, 25-dihydroxyvitamin D3 stimulates adipocyte differentiation in cultures of fetal rat calvaria cells: comparison with the effects of dexamethasone. Endocrinology. 1994;134(5):2221-9.

56. Tansey J, Sztalryd C, Hlavin E, Kimmel A, Londos C. The central role of perilipin a in lipid metabolism and adipocyte lipolysis. IUBMB Life. 2004; 56(7):379-85.

57. Vazquez G, Boland R, de Boland AR. Modulation by 1, $25(\mathrm{OH})$ 2-vitamin D3 of the adenylyl cyclase/cyclic AMP pathway in rat and chick myoblasts. Biochim Biophys Acta, Mol Cell Res. 1995;1269(1):91-7.

58. Kitamura T, Kitamura Y, Kuroda S, Hino Y, Ando M, Kotani K, Konishi H, Matsuzaki H, Kikkawa U, Ogawa W. Insulin-induced phosphorylation and activation of cyclic nucleotide phosphodiesterase 3B by the serinethreonine kinase Akt. Mol Cell Biol. 1999;19(9):6286-96.

59. Manna P, Achari AE, Jain SK. Vitamin D supplementation inhibits oxidative stress and upregulate SIRT1/AMPK/GLUT4 cascade in high glucose-treated 3T3L1 adipocytes and in adipose tissue of high fat diet-fed diabetic mice. Arch Biochem Biophys. 2017;615:22-34.

60. Koh Y-K, Lee M-Y, Kim J-W, Kim M, Moon J-S, Lee Y-J, Ahn Y-H, Kim K-S. Lipin1 is a key factor for the maturation and maintenance of adipocytes in the regulatory network with CCAAT/enhancer-binding protein $a$ and peroxisome proliferator-activated receptor ү2. J Biol Chem. 2008;283(50): 34896-906.

61. Kong J, Li YC. Molecular mechanism of 1, 25-dihydroxyvitamin D3 inhibition of adipogenesis in 3T3-L1 cells. Am J Physiol Endocrinol Metab. 2006;290(5): E916-24.

\section{Publisher's Note}

Springer Nature remains neutral with regard to jurisdictional claims in published maps and institutional affiliations.

Ready to submit your research? Choose BMC and benefit from:

- fast, convenient online submission

- thorough peer review by experienced researchers in your field

- rapid publication on acceptance

- support for research data, including large and complex data types

- gold Open Access which fosters wider collaboration and increased citations

- maximum visibility for your research: over $100 \mathrm{M}$ website views per year

At BMC, research is always in progress.

Learn more biomedcentral.com/submissions 